\title{
Canada's Refugee Status Determination System and the International Norm of Independence
}

\author{
Gerald P. Heckman
}

\section{Abstract}

Refugee protection decisions engage migrants' fundamental life, liberty, and security of the person interests. As a result, refugee protection claimants enjoy institutional and procedural rights under conventional international law. These include the right to a fair adjudication of their protection claims by an independent tribunal. To be independent, a tribunal must meet the formal guarantees of security of tenure, financial security, and administrative independence and must actually be independent, in appearance and practice, from the executive and legislature, particularly in the appointments process. Refugee protection decisions must be made by first instance adjudicative bodies that either fully comply with the requirements of tribunal independence or whose decisions are subject to subsequent review by a tribunal that meets these requirements and has sufficient jurisdiction over the merits of the dispute. The Canadian refugee protection system fails, in certain respects, to meet international standards of independence. The Canadian Immigration and Refugee Board's Refugee Protection Division enjoys statutory, objective badges of independence and appears to operate independently of the executive. However, the independence of Canadian officials engaged in eligibility determinations and in pre-removal risk assessments is very much in question because they have a closer relationship to executive law enforcement functions.

\section{Résumé}

Les décisions sur la protection des réfugiés ont un impact sur les intérêts fondamentaux des migrants ayant trait à leur vie, leur liberté et la sécurité de leur personne. Par conséquent, les demandeurs du statut de réfugié bénéficient de droits de nature institutionnelle ainsi que de droits procéduraux en droit international classique. Cela comprend le droit à une décision impartiale sur leurs demandes de protection par un tribunal indépendant. Pour être indépendant, un tribunal doit satisfaire aux garanties formelles d'inamovibilité, de sécurité financière et d'indépendance administrative, et doit effectivement être indépendant aussi bien en apparence que dans la pratique, des organes exécutifs et législatifs, tout particulièrement en ce qu'il s'agit du processus pour les nominations. Les décisions sur la protection des réfugiés doivent être rendues par des organismes d'arbitrage de première instance qui soit, satisfaient pleinement aux conditions d'indépendance de tribunal, ou dont les décisions sont sujettes à la révision ultérieure par un tribunal qui satisfait à ces conditions et qui possède suffisamment de juridiction sur le fond du différend. Le système canadien de protection des réfugiés ne satisfait pas, à certains égards, aux normes internationales en matière d'indépendance. La Section de la protection des réfugiés de la Commission de l'immigration et du statut de réfugié du Canada jouit de symboles objectifs d'indépendance statutaire et semble opérer indépendamment de l'organe exécutif. Cependant des doutes graves planent sur l'indépendance des fonctionnaires canadiens qui soccupent de détermination de la recevabilité et d'examen des risques avant renvoi, car ils ont un lien plus rapproché avec des fonctions exécutives d'application des lois.

\section{Introduction}

In 1985, the Supreme Court of Canada determined that Canada's refugee determination system violated the constitutional right of refugee protection claimants to security of the person because refugee protection claims could be denied without giving claimants an in-person hearing or disclosure of crucial country conditions information relied upon by the decision makers. ${ }^{1}$ The Singh decision was a watershed moment in the development of Canada's refugee determination 
system. The Canadian government's response was to create an independent agency-the Immigration and Refugee Board (IRB) - to hear, in person and at first instance, the claims of all eligible refugee protection claimants. Though a significant measure of refugee protection responsibility has been entrusted to public servants in Canada's Department of Citizenship and Immigration (CIC) under the current immigration and refugee protection law, the Refugee Protection Division (RPD) of the IRB remains a central, defining, and distinctive feature of Canada's refugee status determination system.

There is some evidence that the Canadian government may be rethinking the role of, or need for, an independent first instance refugee protection tribunal. In 2003, under the previous Liberal administration, then Immigration Minister Denis Coderre publicly proposed removing initial decisionmaking authority over refugee claims from the IRB and conferring it on CIC officials. ${ }^{2}$ More recently, the minority Conservative government's failure to replace, in a timely manner, IRB members whose appointments had expired led to a 33 per cent vacancy rate on the Board and a soaring backlog of refugee claims. Opposition Members of Parliament charged that the government was seeking to manufacture a crisis in Canada's refugee determination system in order to scrap the IRB and replace it with a less generous system of protection. $^{3}$

I argue that no changes to the current refugee determination system that would diminish the role of independent agencies in favour of the increased involvement of government officials should be adopted without assessing and ensuring their conformity with international norms of independence. There are three parts to this article. In the first, I describe the scope and content of the right at international law to a fair hearing before an independent tribunal, as defined in article 14 of the International Covenant on Civil and Political Rights (ICCPR $)^{4}$ and article 6 of the European Convention for the Protection of Human Rights and Fundamental Freedoms (ECHR). ${ }^{5}$ In the second part, I briefly describe the decisionmaking structure of Canada's refugee determination system, and in the final part, I assess the extent to which this system diverges from international norms of tribunal independence. I conclude that Canada's refugee determination system in its current form does not guarantee all refugee protection claimants that to which they are entitled under international law: a hearing before an independent tribunal with sufficient jurisdiction over the merits of their claims.

\section{The Guarantee of Independence in Conventional International Law}

International human rights law entitles each individual to a fair and public hearing by an independent and impar- tial tribunal in the determination of his or her rights and obligations. This right is expressly guaranteed in several international declarations and conventions, including the Universal Declaration of Human Rights, ${ }^{6}$ the ICCPR, the ECHR, and the American Convention on Human Rights. ${ }^{7}$ It has been observed, based on a wide-ranging review of state constitutions, legislation, and supporting state practice regarding judicial independence, that "the general practice of providing independent and impartial justice is accepted by states as a matter of law" and is thus a customary norm of international law. ${ }^{8}$ This part focuses on how the scope and content of the norm of tribunal independence are defined under article 14(1) ICCPR and article 6(1) ECHR.

Ratified by Canada and in force since 1976, the ICCPR's provisions are binding on Canada under international law, which means that at the very least, Canadian courts should, where possible, interpret Canadian law in a manner that comports with Canada's obligations under the Covenant. ${ }^{9}$ Moreover, Canada has claimed in its regular reports to the UN Human Rights Committee to have implemented the terms of the Covenant by, among other measures, enacting the Charter of Rights and Freedoms. ${ }^{10}$ The Human Rights Committee, established under the Covenant, monitors the implementation of the Covenant by reviewing the periodic reports of states parties and issues commentaries on the meaning and scope of the Covenant's provisions. Canada has recognized the jurisdiction of the Committee to receive and consider communications from individuals alleging a breach by Canada of their rights under the Covenant. ${ }^{11}$ I pay close attention to the Committee's pronouncements on the scope and content of the norm of tribunal independence expressed in article 14, and also consider the jurisprudence of the European Court regarding the norm of tribunal independence expressed in article 6 ECHR, a provision broadly analogous to article 14 ICCPR, which offers insight into the nature and extent of Canada's international obligations.

\section{Scope of the Right to an Independent Tribunal}

Does article 14(1) guarantee the right to a hearing before an independent tribunal in the context of refugee status determination? In 2007, the Human Rights Committee expressed the view that "proceedings relating to an alien's expulsion" do not fall within article 14(1), ${ }^{12}$ a decision consistent with the case law of the European Court of Human Rights in respect of article 6(1). ${ }^{13}$ I claim that these decisions by the Committee and the European Court should not extend to refugee status determinations because they are inconsistent with the purpose and drafting history of articles 14(1) ICCPR and 6(1) ECHR and with the general framework governing the application of these provisions to adjudications in the public law realm. 
The right to an independent tribunal in public law adjudications

\section{Article 14(1) of the ICCPR}

Article 14(1) ICCPR provides that:

All persons shall be equal before the courts and tribunals. In the determination of any criminal charge against him, or of his rights and obligations in a suit at law, everyone shall be entitled to a fair and public hearing by a competent, independent and impartial tribunal established by law.

The right of persons to "a fair and public hearing by a competent, independent and impartial tribunal established by law" applies only to the determination of a criminal charge and to the determination of a person's "rights and obligations in a suit at law". The travaux préparatoires to the Covenant and the Committee's views and comments indicate that some proceedings of an administrative nature are captured by article 14(1) and subject to its requirements of fairness, independence, and impartiality. ${ }^{14}$

The travaux préparatoires reveal a debate among drafting committee delegates about whether the right to a fair hearing before an independent tribunal in non-criminal matters should be restricted to proceedings that determined "civil" or "private" rights and obligations or extended to proceedings between individuals and the state, including administrative matters. ${ }^{15}$ The compromise accepted by the committee was to remove the adjective "civil" but qualify the term "rights and obligations" with the phrase "in a suit at law," a formulation intended to emphasize that "appealing to a tribunal was an act of a judicial nature." 16 The consensus among the drafters was to extend article 14(1) protections to disputes between individuals and the state. ${ }^{17}$ However, the term "in a suit at law" was intended to remove some matters from the scope of article 14(1), like "administrative proceedings in the first instance as to subject matters unrelated to human-rights concerns, such as taxation." 18

The Human Rights Committee appeared to confirm that article 14(1) applies to administrative proceedings in Y.L. $v$. Canada. ${ }^{19}$ The author of the communication, a soldier discharged from the armed forces, unsuccessfully applied to the Canadian Pension Commission for a disability pension. He appealed to the Pension Review Board, which confirmed the Commission's rulings. He claimed that he had been denied a fair and public hearing in violation of article 14(1). Canada replied that the communication was inadmissible because Pension Review Board proceedings were not a "suit at law": the relationship between the author, a member of the armed forces, and the state was a matter of public law, and did not concern "civil rights and obligations," an expression taken from the French-language version of article 14(1), which refers to "contestations sur ses droits et obligations de caractère civil." The Human Rights Committee held that:

... the concept of a "suit at law" or its equivalent in the other language texts is based on the nature of the right in question rather than on the status of one of the parties (governmental, parastatal or autonomous statutory entities), or else on the particular forum in which individual legal systems may provide that the right in question is to be adjudicated upon, especially in common law systems where there is no inherent difference between public law and private law and where the courts normally exercise control over the proceedings either at first instance or on appeal specifically provided by statute or else by way of judicial review. In this regard, each communication must be examined in light of its particular features. ${ }^{20}$

In relation to the author's pension claim, the Committee noted that it was clear "that the Canadian legal system subjects the proceedings in [the various administrative bodies before which the author pursued his claim] to judicial supervision and control, because the Federal Court Act does provide the possibility of judicial review in unsuccessful claims of this nature." ${ }^{21}$ The first instance hearing before the Pension Review Board, coupled with the availability of judicial review of the Board's decision, appeared to comply with article $14(1) .^{22}$

Although the Committee did not expressly state that the pension proceeding was a suit at law, this can be implied from its views, ${ }^{23}$ and many academic commentators have concluded that the Committee recognized that the Pension Board proceedings concerned the determination of rights and obligations in a suit at law. ${ }^{24}$ The Committee has since held that article 14(1) applies to proceedings involving governments as parties, including wrongful dismissal proceedings brought by civil servants against their state employers ${ }^{25}$ and to child protection proceedings under child welfare legislation. ${ }^{26}$ In contrast, the selection and appointment of judges by Cyprus's Supreme Council of Judicature did not determine rights and obligations in a suit at law because they concerned the denial of an application for employment in the judiciary by a body exercising a "non-judicial" task. ${ }^{27}$

Like the travaux préparatoires, which suggest that the phrase "suit at law" was added to emphasize that proceedings subject to article 14(1) would be of a "judicial" nature, the Committee's allusion to "non-judicial" and "judicial" tasks is reminiscent of the efforts of Canadian courts to determine the threshold for the application of the common law duty of procedural fairness, and in particular their distinction between administrative decisions and judicial decisions. ${ }^{28}$ Drawing on this analogy, the Committee's focus on whether the im- 
pugned decision is of a judicial nature can be reconciled with its decision in Y.L., where the Committee was essentially preoccupied with the following question: was the author's claim the kind of claim over which courts would normally exercise control and supervision to ensure it was decided fairly? In Kazantzis, it found that the author's application for a judicial appointment did not entail decision making of a "judicial" nature. Courts would not normally recognize that the author was owed a duty of fairness for the determination of this kind of claim, and would not enforce such a duty. Therefore, under the Y.L. test, claims of this nature were not within the scope of article 14(1). Under this approach, to ask whether article 14(1) applies to the determination of an individual's claim is to ask whether a duty of fairness is owed to the claimant. Under the Y.L. test, as at common law, the answer to that question depends on the nature of the claim. ${ }^{29}$ If the determinations required to reach a decision on the author's claim are closer to judicial than legislative decision making and if that decision significantly impacts the author's life, the claim is of a kind normally subject to judicial supervision and control to ensure its fair determination; the Y.L. test is satisfied and article 14(1) applies. If this reasoning is correct, there should be no doubt that article 14 applies to refugee status determinations and refugee protection decisions which have long attracted the application of the duty of procedural fairness. Before examining this question in greater detail, it is instructive to review the rules governing the application of article 6(1) ECHR to public law proceedings.

\section{Article 6(1) of the ECHR}

Article 6(1) states:

In the determination of his civil rights and obligations or of any criminal charge against him, everyone is entitled to a fair and public hearing within a reasonable time by an independent and impartial tribunal established by law.

The extent to which article 6(1) applies to public law disputes is also a contentious question. The European Court has applied article 6(1) outside the criminal context where the impugned proceedings involve a dispute ("contestation") over a "right," the impugned proceedings lead to a "determination" of the right, and the right is of a "civil" nature.

The Court must first decide whether there is a dispute over a "right" which can be said on arguable grounds to be recognized under domestic law. The concepts of "right" and "obligation" have an autonomous meaning under the European Convention and the European Court is not bound by a state's determination of whether the national legal system classifies an interest or privilege as a "right." ${ }^{30}$ An entitlement or right expressly provided for by statute is clearly "recognized under domestic law". A right may also be found to exist in the face of a broad statutory discretion to confer a benefit or issue a license, even where the applicant cannot claim entitlement to a specific outcome. ${ }^{31}$ The Court has held that the "contestation" must be of a genuine and serious nature; may relate to the actual existence of a right, to its scope, or to the manner in which the right may be exercised; and may concern questions of both fact and law. ${ }^{32}$ The impugned proceedings must lead to a "determination" of the civil right or obligation: they must be "decisive for," "affect," or "relate to" the determination or exercise of a "civil" right. ${ }^{33}$ Finally, the entitlement to a hearing by an independent tribunal is guaranteed in cases involving the determination of individuals' "civil rights and obligations." A major point of contention has been whether "civil" should be equated with "private," and article 6(1) restricted to proceedings meant to determine individual property rights or rights arising in tort or contract law. As described previously, there are strong arguments, based on the drafting history of articles 14(1) ICCPR and 6(1) ECHR, that this was not the intention of the drafters of either provision, ${ }^{34}$ and that "civil" rights covers the determination of all legal rights outside the sphere of criminal law. ${ }^{35}$ The European Court recognizes that the concept of "civil right or obligation" has its own meaning in European Convention law, that it does not exclude disputes between individuals and the state acting in its sovereign capacity, and that the character of the legislation which governs the matter to be determined and the nature of the authority which has jurisdiction in the matter (ordinary court or administrative body) are of little consequence in determining whether a right or obligation is civil in character. ${ }^{36}$

Applying these principles on a case by case basis, the European Court has extended the scope of article 6(1) beyond disputes concerning private rights to proceedings with a strong "public" flavour. The Court identified a dispute involving the determination of "civil rights" and thus governed by article 6(1) in each of the following cases: the withdrawal of a liquor permit (despite Sweden's claim that regulating alcohol distribution and consumption was part of its social policy and fell within an essential field of public law); ${ }^{37}$ the decisions of professional disciplinary tribunals to restrict or eliminate individuals' right to exercise professions; ${ }^{38}$ disputes regarding individuals' entitlement to health insurance under social security legislation; ${ }^{39}$ and an individual's claim of entitlement to welfare allowances. ${ }^{40}$

The right to an independent tribunal in the refugee status determination and protection context

Having reviewed the general framework for determining the applicability of articles 14(1) ICCPR and 6(1) ECHR, particularly in the public law context, I now turn to the ap- 
plication of these provisions in the migration context, and specifically to refugee status determinations. As noted earlier, the Committee's Y.L. decision essentially held that article 14(1) applies to claims of a kind normally subject to judicial supervision and control. Refugee status determinations and refugee protection proceedings involve the application of legal criteria to a factual matrix particular to each individual claimant. Such determinations are specific and judicial in nature and have a significant impact on fundamental individual interests. The claims involved in such proceedings are thus clearly of a kind normally subject to judicial supervision and control and should on this basis attract article 14(1) guarantees.

It also seems clear that under the European Court's relatively broad interpretation of article 6(1), the provision should apply to refugee status determination proceedings since they are determinative of refugee claimants' civil rights. An individual is a refugee as soon as she meets the criteria set out in the Refugee Convention. ${ }^{41}$ In practice, however, she may only exercise the rights and enjoy the benefits that attach to refugee status, described in the Refugee Convention, if her surrogate state recognizes her status, usually after a refugee status determination proceeding. ${ }^{42}$ In particular, Chapter II requires refugees' "surrogate state" to recognize, among other rights, property and commercial rights and family law rights long recognized by the European Court as falling within the category of "civil law" rights for purposes of the application of article $6(1) .{ }^{43}$ Similarly, the guarantees set out in Chapter III regarding the rights of refugees to engage in wage-earning employment and, in particular, to practice a profession have also been accepted by the European Court as rights of a "civil law" nature. ${ }^{44}$ Chapter IV provides that the surrogate state must accord to refugees lawfully staying in its territory the same treatment as it accords its own nationals in respect of public relief and assistance ${ }^{45}$ and social security. ${ }^{46}$ Claims to such benefits have also been recognized by the European Court as falling within the scope of article 6(1). Since refugees may exercise these rights or enjoy these benefits-many of which have "a civil law character"-only if the surrogate state recognizes their status, refugee status determination proceedings certainly "affect" or "are related to" and arguably are "directly decisive" for the question whether a civil law right can be exercised. ${ }^{47}$ Under the interpretive framework followed by the European Court in contexts other than migration, they fall squarely within the scope of article 6(1).

Nevertheless, in Maaouia v. France, where a Tunisian immigrant who was ordered deported after committing serious criminal offences challenged the fairness of France's deportation procedures, the European Court held that decisions regarding the "entry, stay and deportation of aliens" do not concern the determination of their civil rights or obligations under article 6(1). ${ }^{48}$ Proceedings for the rescission of exclusion orders did not concern the determination of aliens' civil rights, even though exclusion orders significantly affected their private and family life and prospects of employment. ${ }^{49}$ The Court based its decision primarily on the Council of Europe's adoption, twenty-four years after the ratification of the European Convention, of a separate protocol providing minimal procedural administrative safeguards to aliens in expulsion proceedings. A majority of the Court accepted that the State Parties to the Convention had not intended immigration proceedings to be covered by article 6(1), and reasoned that the protocol was adopted precisely to fill the gap resulting from the lack of article 6(1) guarantees. ${ }^{50}$ Though Maaouia did not involve a challenge to refugee status determination proceedings and the Court did not pronounce itself on the application of article 6(1) to such proceedings, it has since asserted that Maaouia stands for the proposition that article 6(1) does not apply to "matters of asylum."51

Dissenting in Maaouia, Judges Loucaides and Traja roundly criticized the majority judgment. First, they rejected its interpretation of the concept of "civil rights" as unduly narrow and at odds with a purposive interpretation of treaties and the drafting history of article 6(1). ${ }^{52}$ "Civil right" should be read to include all legal rights that were not of a criminal nature, ${ }^{53}$ because this interpretation enhanced individual rights in line with the object of the European Convention. ${ }^{54}$ Further, it was inconceivable that a convention intended to implement the rule of law could provide for the fair administration of justice in respect of rights between individuals but fail to do so in respect of rights and obligations "vis-à-vis the administration where an independent judicial control is especially required for the protection of individuals against the powerful authorities of the State." 55 Second, the dissent questioned the majority's reliance on the protocol, arguing that while its procedural protections for the expulsion of aliens were intended to govern proceedings before competent administrative authorities, they did not purport to restrict any judicial guarantees that aliens enjoyed under article 6(1), but instead supplemented these guarantees. ${ }^{56}$ The Council of Europe's decision to require states to put in place an administrative authority governed by minimal procedural guarantees could not be taken, without express language, to restrict aliens' right to a fair hearing under article 6(1). A protocol entered into long after the ratification of the European Convention and meant to form part of the Convention could not qualify or abolish the human rights previously safeguarded in the main body of the Convention. ${ }^{57}$

The Maaouia dissent advances powerful reasons against excluding migration proceedings from the scope of article 6(1) based on a narrow interpretation of the term "civil rights." Refugee status determination proceedings, more- 
over, appear to fall within the scope of article 6(1) as defined by the European Court in contexts other than migration. The broad interpretation urged by the dissenting judges is even more compelling in the context of article 14(1) ICCPR, whose drafters expressly dropped the adjective "civil" from the English-language version to include public law proceedings within its scope, ${ }^{58}$ and is consistent with other regional human rights instruments which do not distinguish between "civil" and "public" law rights. ${ }^{59}$ The result in Maaouia is driven less by the text of article 6(1) and the Court's article 6(1) jurisprudence than by the implied effect of a specific protocol. And yet, the Human Rights Committee appears to have followed the European Court's lead. In P.K. v. Canada, ${ }^{60}$ P.K. was denied refugee status by the IRB on grounds of credibility and denied leave to apply for judicial review of this decision by the Federal Court, and she unsuccessfully applied for a pre-removal risk assessment and for permanent residence on humanitarian and compassionate grounds. Following her removal to Pakistan, she claimed a violation of article 14(1) because the risk assessments preceding her deportation were neither fair nor independent. Canada argued that P.K.'s claim was inadmissible because article 14(1) did not apply. Refugee determination proceedings were "public law" proceedings, not a criminal charge or suit at law, and their fairness was guaranteed by article 13 ICCPR. ${ }^{61}$ Canada argued that articles 6(1) ECHR and 14(1) ICCPR were "equivalent," that the European Court's case law was "persuasive" and that the Committee should follow Maaouia. ${ }^{62}$ The Committee held that:

[T]he concept of a "suit at law" under article [14(1)] ... is based on the nature of the right in question rather than on the status of one of the parties. In the present case, the proceedings relate to the author's right to receive protection in the State party's territory. The Committee considers that proceedings relating to an alien's expulsion, the guarantees in regard to which are governed by article 13 of the Covenant, do not also fall within the ambit of a determination of "rights and obligations in a suit at law", within the meaning of article [14(1)]. It concludes that the deportation proceedings of the author do not fall within the scope of article [14(1)], and are inadmissible ... ${ }^{63}$

The Committee appears to have accepted that, by analogy to the role of the protocol in Maaouia, article 13 ICCPR is a complete code governing migration proceedings and, as such, excludes the application of the more general article 14(1). This is not a plausible interpretation of article 14, for several reasons. First, article 13 applies only to decisions pursuant to which non-citizens lawfully present in a State Party are expelled. ${ }^{64}$ It does not apply to proceedings, like refugee determination proceedings, that do not of themselves lead to expulsion, ${ }^{65}$ but that are a necessary precondition to the exercise of non-citizens' civil rights, as demonstrated above. A second reason to doubt that article 13 precludes the application of article 14(1) to refugee protection proceedings is that article 13 applies to all non-citizens facing expulsion proceedings, including individuals present on a state's territory who have simply overstayed their visitor's or student visa, and for whom expulsion may engage no significant life, liberty, and security of the person interests. An interpretation of the Covenant that entitles refugee protection claimants, whose claims of well-founded fear of persecution in their home countries engage such interests, to procedural and institutional rights no higher than those enjoyed by overstayers must be rejected. Construing article 13 to preclude the application of article 14(1) to refugee determination or expulsion proceedings is contrary to a purposive interpretation of these fundamental human rights. It is preferable to interpret article 13 as requiring that the authority competent to order a noncitizen's expulsion at least offer that individual a procedurally fair administrative reconsideration of its expulsion decision. This requirement should not be taken, without express language, to remove the state's obligation to also provide for a fair hearing before an independent tribunal, either through a subsequent hearing before an administrative body or through judicial review. ${ }^{66}$ Maaouia and P.K. lack any reasoning that could justify exempting refugee status determinations from the general frameworks developed by the European Court and the Committee to determine the applicability of articles 6(1) ECHR and 14(1) ICCPR. Protection claims, as well as claims regarding juridical status, the right to practice a profession, and the entitlement to social benefits which may flow from the recognition of refugee status in refugee status determination proceedings, are of a kind over which courts would normally exercise control and supervision to ensure they were decided fairly. They should be governed by article 14(1) ICCPR.

\section{Content of the Right to an Independent Tribunal The ICCPR}

Article 14 ICCPR requires that determinations of rights and obligations in a suit at law be made by a competent, independent and impartial tribunal established by law. Administrative authorities, as well as national civil courts, are considered "tribunals" under article 14(1). ${ }^{67}$ In determining whether a tribunal is independent, the Committee considers "the manner in which judges are appointed, the qualifications for appointment, and the duration of their terms of office; the conditions governing their promotion, transfer and cessation of their functions; and the actual independence of the judiciary from the executive branch and the legislature." 68 These criteria were inspired by a United Nations initiative to define 
the minimum standards flowing from the right to an independent tribunal guaranteed in the UDHR and ICCPR. ${ }^{69}$ The United Nations' "principal instrument" for defining judicial independence is a document titled "Basic Principles on the Independence of the Judiciary," 70 endorsed by the UN General Assembly. ${ }^{71}$ In parallel, the UN Commission on Human Rights' Sub-Commission on Prevention of Discrimination and Protection of Minorities appointed a special rapporteur, Dr. L. M. Singhvi, to conduct an exhaustive study of state constitutions, legislation, and supporting state practice and produce a report on the independence and impartiality of the judiciary. In his seminal final report and a follow-up report, Dr. Singhvi developed a Draft Universal Declaration on the Independence of Justice. ${ }^{72}$ The Basic Principles and the Singhvi Declaration include the traditional guarantees of security of tenure, financial security, and administrative control recognized in Canadian jurisprudence on independence. ${ }^{73}$ In addition, both documents require that judges be appointed and promoted based on their integrity, training, and qualifications rather than improper motives. ${ }^{74}$ Dr. Singhvi notes that in relation to the principle of independence, the doctrine of separation of powers postulates, among other things, "the insulation of the judiciary in respect of appointment, promotion, posting, transfer, removal, emoluments and other conditions of work and service from external and extraneous influence of legislative and the executive." 75

Though developed primarily in relation to the independence of the judiciary, these guarantees are relevant to the independence of administrative decision makers. ${ }^{76}$ The principle of independence applies to both judges and "others, who, without being judges in the formal sense, perform judicial roles and functions."77 However, in its application to "administrators and policymakers" with adjudicative functions, the principle of independence "cannot be secured in the same way as in the case of judges and tribunals whose functions are primarily judicial and who belong by their appointment to the machinery of justice":

The terms and tenures of those who are not a part of the judiciary are necessarily different; so are their background and appointment procedures. Safeguards applicable to members of the judiciary cannot, therefore, be made applicable to them. They may nevertheless be called upon to discharge duties of a judicial and quasi-judicial nature in an impartial and independent manner. ( ... ) With regard to those who also perform judicial or quasi-judicial roles but who are [not] strictly a part of the judiciary, judicial standards and other safeguards apply as far as possible. ${ }^{78}$
In sum, the safeguards dictated by the principle of independence apply to the fullest extent to regular courts and to tribunals exercising primarily judicial functions. In the case of administrators and policy makers who also have an adjudicative function, they apply by analogy with suitable modifications and "judicial" safeguards apply only as far as possible. The principle of independence remains relevant along the entire decision-making spectrum but requires stronger safeguards for decision makers whose functions more closely resemble those of courts.

The Committee has had occasion to elaborate on the requirements of the article 14(1) guarantee of independence in its concluding remarks on the periodic reports of various state parties to the Covenant and in its views on individual communications. However, its interventions have largely been limited to cases of egregious interference by the executive with the appointment and tenure of judges ${ }^{79}$ and article 14(1) has seldom been applied in the context of administrative decision making.

\section{The ECHR}

Article 6(1) ECHR guarantees individuals whose civil rights are to be determined a right of access to proceedings before tribunals, including administrative tribunals, ${ }^{80}$ whose organization and composition meet minimum standards of independence and impartiality. Independence requires that decision-making bodies be free to exercise their powers without interference from the state's executive or legislature or from the parties to the dispute. ${ }^{81}$ While article 6 does not require states to comply with "theoretical constitutional concepts" regarding the separation of the judicial from the legislative or executive powers, ${ }^{82}$ these are increasingly recognized as an important foundation of the principle of independence. ${ }^{83}$

\section{The principal guarantors of independence}

In the seminal case of Campbell and Fell, the Court sought to determine whether a prison's "Board of Visitors," charged with supervising the administration of a prison and adjudicating prisoners' alleged violations of prison regulations, was independent. In determining whether a tribunal is independent, the Court held, three criteria were relevant: the manner of appointment of the tribunal's members and their term of office, the existence of guarantees against outside pressure, and whether the tribunal presents an appearance of independence.

The manner of appointment of tribunal members and their term of office. The fact that tribunal members are appointed by the executive does not deprive them of independence. The executive can even provide tribunal members with guidelines regarding the performance of their functions without

(C) Gerald P. Heckman, 2008. This open-access work is licensed under a Creative Commons Attribution-NonCommercial 4.0 International License, which permits use, reproduction and distribution in any medium for non-commercial purposes, provided the original author(s) are credited and the original publication in Refuge: Canada's Journal on Refugees is cited. 
imperiling their independence as long as it does not instruct them in their adjudicatory role. ${ }^{84}$ The Court has upheld the independence of specialized boards of expert civil servants who were statutorily and constitutionally required to discharge their duties independently and not be subject to instructions from the executive, ${ }^{85}$ and whose independence was strengthened by a five-year term and virtual irremovability guaranteed by law. ${ }^{86}$ In deciding whether decision makers' terms of office are sufficient to guarantee independence, the Court has applied a flexible, contextual standard. ${ }^{87}$

The existence of guarantees against outside pressure. Article 6(1) guarantees the irremovability of judges during their term of office. In the absence of formal guarantees of independence, such as statutorily mandated security of tenure, the Court examines whether these guarantees are recognized in practice and whether others are present. It may regard a tribunal as independent provided its members are irremovable in practice. ${ }^{88}$ For example, the independence of a Court Martial was not compromised by the fact that its permanent president, appointed for a four-year term to serve on panels with an independent judge advocate and two serving officers, did not enjoy formal security of tenure because permanent presidents enjoyed de facto security of tenure: they had never been removed from office, their position was the last of their careers, eliminating promotions concerns as a possible influence, and they worked outside the chain of command. ${ }^{89}$ Serving officers, in contrast, were not independent. These relatively junior officers were appointed on an ad hoc basis for individual proceedings, had no legal training, and were not statutorily protected from external army influence while hearing a case. They were exposed to outside pressure that jeopardized their independence. They were members of the army, which was directed by the executive, and they were subject to military discipline and assessment reports that impacted their careers. Rules governing their selection, the requirement to swear an oath promising impartiality, the confidentiality of deliberations, and the rule that junior members express their view on verdict and sentence first were insufficient guarantees against outside pressure. ${ }^{90}$ However, the independence of junior members of a Court Martial could be assured with additional safeguards. ${ }^{91}$ One such safeguard was the provision of training material that explained Court Martial procedures and the role of each decision maker in the proceedings, and that instructed them of "the need to function independently of outside or inappropriate influence or instruction and of the importance of this being seen to be done," providing "practical and precise indications of how this could be achieved or undermined in a particular situation." ${ }^{2}$ Such instructions brought home to the members the "vital importance of independence" and provided a "significant impediment to any inappropriate pressure being brought to bear." ${ }^{\text {"93 }}$ Another im- portant safeguard was that any opinion expressed or vote cast by officers during court martial proceedings remained confidential, preventing superiors from subjecting their performance to assessment reports. ${ }^{94}$

Whether the tribunal presents an appearance of independence. This third criterion operates in cases where the decision makers meet the traditional guarantees of independence but perform overlapping adjudicative and prosecutorial functions or, on a case-specific basis, are subject to executive interference. For example, a penitentiary's Board of Visitors could still be viewed as independent despite its dual role in supervising prison administration and adjudicating inmates' violations of prison rules, which placed it in frequent contact with prison officials and inmates. ${ }^{95}$ In contrast, a minister's rarely used power to revoke a planning inspector's authority to decide an appeal deprived the inspector of the requisite appearance of independence. ${ }^{96}$

\section{Judicial review and independence}

Article 6(1) ECHR does not guarantee parties the opportunity to directly submit disputes over civil rights to independent tribunals. For reasons of flexibility and efficiency, a decisionmaking process may employ, at first instance, decision makers that do not satisfy the article 6(1) requirements in every respect. ${ }^{97}$ It will comply with article 6(1) as long as a tribunal meeting these requirements eventually reviews the dispute. ${ }^{98}$ This "composite approach" 99 was first adopted in Albert and Le Compte, which involved a professional discipline tribunal's decision to suspend the applicant doctors from medical practice:

... [T] he Convention calls at least for one of the two following systems: either the jurisdictional organs themselves comply with the requirements of Article 6(1), or they do not so comply but are subject to subsequent control by a judicial body that has full jurisdiction and does provide the guarantees of Article 6(1). ${ }^{100}$

But what did "full jurisdiction" mean? Where professional discipline adjudications involved two decision-making bodies, one of which made final and binding findings of fact and the other final and binding findings of law, the Court held that each body was required to meet the requirements of article 6(1). ${ }^{101}$ In a series of cases from the United Kingdom, the European Court determined that judicial review of local authorities' child access orders did not comply with article 6(1). ${ }^{102}$ Each case was brought by natural parents contesting the decision of a local authority to restrict their access to a child in the authority's care as an infringement of their right to private and family life under article 8 ECHR. The Court observed that the composite approach required that parents "have the local authority's decision reviewed by a tribunal 
having jurisdiction to examine the merits of the matter." 103 Judicial review before the English courts was insufficient because it was "concerned with reviewing not the merits of the decision in question but rather the decision making process itself." 104

In some decision-making contexts, the European Court has relaxed the requirements of its composite approach to the guarantee of tribunal independence. ${ }^{105}$ Courts reviewing a first-instance decision that does not comply with article $6(1)$, perhaps because the decision maker is not independent, no longer need "full" jurisdiction over the claim; they just need "enough" jurisdiction to deal with the grounds of review point by point. In Bryan v. U.K., the European Court held that whether a reviewing court has "enough" jurisdiction depends on the manner in which the first-instance decision was arrived at, the content of the dispute including the grounds of review and the subject matter of the decision. ${ }^{106}$ The first two factors are usually considered together. Thus, if the dispute is over a policy question, the initial decision could be made by a decision maker lacking independence as long as Wednesbury-like review is available. ${ }^{107}$ If the dispute concerns findings of fact, such limited judicial review is sufficient only if the initial decision is taken in a quasi-judicial process (i.e., a hearing) by a decision maker bearing some of the badges of independence. ${ }^{108}$ The third factor, the subject matter of the decision under review, is crucial. Proceedings that involve fundamental rights or interests demand more safeguards at first instance and more intensive review. These include child access proceedings, for which Wednesbury reasonableness review was, according to the European Court, insufficient to satisfy article 6(1). The House of Lords has held that article 6(1) requires the highest standards of independence for decisions touching on basic rights such as liberty rights engaged by the criminal process, "private" rights, and rights protected by the European Convention, including the right to a private and family life. ${ }^{109}$

In sum, conventional international law generally entitles individuals to have their rights and obligations adjudicated by an independent tribunal. Under the ECHR and ICCPR, the right to an independent tribunal is limited to the determination of "civil" rights and obligations or of rights and obligations "in a suit at law." However, the Human Rights Committee, other UN bodies, and the European Court have interpreted the right to an independent tribunal purposively, and have recognized its application to decision making by administrative tribunals in public law contexts ranging from town planning and economic regulation to social assistance and human rights protection. While they have recognized the importance of formal guarantees of security of tenure, financial security, and administrative independence to ensure tribunal independence, they also emphasize the need to en- sure that tribunals are "actually" independent, in appearance and practice, from the executive branch and the legislature, particularly in the appointments process. States may design decision-making schemes involving adjudicative bodies that do not fully comply with the requirements of tribunal independence, so long as their decisions are subject to subsequent review by a tribunal that meets these requirements and has sufficient jurisdiction over the merits of the dispute. It is difficult to pinpoint precisely what degree of jurisdiction over the merits is "sufficient" for judicial review of administrative decision making to satisfy the international norm of tribunal independence since, as demonstrated by the foregoing review of the European Court's jurisprudence, the meaning of these concepts is continuously evolving. However, disputes involving fundamental human rights adjudicated at first instance by non-independent decision makers will require more intense review by independent tribunals with jurisdiction over questions of fact and law. Before applying these principles to the design of Canada's refugee status determination system, I briefly describe this system in the following section.

\section{Canada's Refugee Protection System}

Canada offers protection to persons who meet the Convention refugee definition 110 and to "persons in need of protection," whose removal from Canada to their country of origin would subject them personally to a danger of torture, a risk to their life, or a risk of cruel and unusual treatment or punishment. ${ }^{111}$

\section{Eligibility}

A person arriving at a Canadian port of entry may make a refugee protection claim to an officer employed by the Canada Border Services Agency (CBSA), an agency reporting to the Minister of Public Safety and Emergency Preparedness. ${ }^{112}$ Persons already in Canada may make a claim to an immigration officer, a public servant designated by the Minister of Citizenship and Immigration (the Minister) to perform specific functions under the $A c t,{ }^{113}$ including determining whether protection claimants are eligible to have their protection claim determined by the IRB's Refugee Protection Division. ${ }^{114}$ A refugee claimant may be ineligible to have her protection claim determined by the RPD in several circumstances, ${ }^{115}$ including where she made a prior protection claim that was rejected by the IRB or determined to be ineligible or to have been withdrawn or abandoned, came directly or indirectly to Canada from a designated "safe third country," or was found inadmissible on grounds of security, violating human or international rights, serious criminality, or organized criminality. Claimants must provide the officer with information needed to establish their identity, background, how they arrived in Canada, and why they are seek- 
ing refugee protection, ${ }^{116}$ and must prove they are eligible. ${ }^{117}$ Eligible claimants complete a Personal Information Form ${ }^{118}$ designed to elicit the information required by the RPD to make a refugee determination decision. ${ }^{119}$ Ineligible claimants are subject to removal from Canada but may apply to the Minister for protection under a pre-removal risk assessment (PRRA) process ${ }^{120}$ and, if successful, receive refugee protection or, at least, a temporary stay of their removal orders. ${ }^{121}$ They may also seek leave to apply for judicial review of their ineligibility decision in the Federal Court.

Claimants found to be ineligible because they came to Canada from a country designated as a safe country by the regulations do not receive a PRRA. ${ }^{122}$ On December 5, 2002, Canada and the United States concluded a Safe Third Country Agreement ${ }^{123}$ providing for the return to the United States of persons seeking refugee protection and arriving in Canada from the United States unless they can establish that an exception to the Agreement applies. ${ }^{124}$ Refugee claimants are excepted from return if they can establish the presence in Canada of a relative with legal status, ${ }^{125}$ are unaccompanied minors, ${ }^{126}$ or present claims that Canadian authorities, in their discretion, decide to examine where they determine it is in the public interest to do so. ${ }^{127}$

In Canada, eligibility decisions under the Safe Third Country Agreement are carried out according to CIC guidelines by officers employed by the CBSA. Claimants must satisfy authorities, on a balance of probabilities, of the existence of a family relationship with an appropriate anchor relative needed to qualify for an exemption. ${ }^{128}$ In most cases, claimants found ineligible to make a refugee claim in Canada under the Agreement are removed the same day as they arrive at the port of entry. ${ }^{129}$ Claimants are entitled to an administrative review: the officer who conducts the examination submits an inadmissibility report and eligibility recommendation to a different officer who reviews the information with the claimant, gives the claimant a chance to respond and makes a final decision on admissibility and eligibility. ${ }^{130}$

\section{The Refugee Protection Division}

The Refugee Protection Division of the IRB is the primary body responsible for refugee protection determination. Its full-time and part-time members, ${ }^{131}$ chosen by a seven-member Selection Advisory Board chaired by the IRB Chair, ${ }^{132}$ are appointed by the Governor-in-Council for a term not exceeding seven years and are eligible for reappointment. ${ }^{133}$ It has exclusive jurisdiction to hear and determine all questions of law and fact in refugee protection determination proceedings. ${ }^{134}$ RPD hearings are held in the claimant's presence, typically before a single member. ${ }^{135}$ Each panel is assisted by an IRB refugee protection officer (RPO) who reviews files to identify issues, conducts research, holds interviews, presents evidence, calls and questions witnesses, makes representations, and generally ensures a full and proper examination of a claim. ${ }^{136}$ RPOs and RPD members question the claimant to "flush out any weaknesses in the claimant's case that might lead to a determination that the claimant is not a person in need of protection," 137 making the RPD hearing a relatively inquisitorial process. In contrast, the claimant's representative seeks to establish that she is a person in need of protection. The Minister of Public Safety and Emergency Preparedness may intervene to oppose the claim. ${ }^{138}$ Individual RPD panel members control the hearing procedure but generally follow IRB guidelines regarding the conduct of the hearing. ${ }^{139}$

A claimant's refugee protection claim is accepted if she establishes that, on the balance of probabilities, she is a Convention refugee or a person in need of protection. ${ }^{140}$ If the RPD rejects a claim, it delivers written reasons to the Minister and claimant, ${ }^{141}$ who is subject to removal from Canada. However, she may apply to the Minister for protection by requesting a PRRA, ask the Minister to allow her to remain in Canada on humanitarian and compassionate $(\mathrm{H} \& \mathrm{C})$ grounds, ${ }^{142}$ and seek judicial review of the RPD's negative decision.

\section{Statutory appeals and other avenues of administrative review}

Claimants may appeal a decision of the RPD to the Refugee Appeal Division (RAD) of the IRB on a question of law, fact, or mixed law and fact. ${ }^{143}$ The provisions implementing the RAD have not been proclaimed into force in the seven years since their enactment. Until they are, failed or ineligible refugee protection claimants have two administrative "review" options: a pre-removal risk assessment and an application for a humanitarian and compassionate review of their case. Unlike a RAD appeal or judicial review, neither option allows the applicant to contest a negative RPD determination.

Persons in Canada subject to a removal order are generally eligible to apply for a PRRA. ${ }^{144}$ Notable exceptions include claimants found ineligible to make a protection claim because they arrived from a designated safe third country or, having been removed after their protection claim was declared ineligible, rejected, withdrawn, or abandoned, returned to Canada within six months of their removal. ${ }^{145}$ The PRRA recognizes that events that occur in a failed claimant's home country after her claim is rejected but before her removal may put her at risk of persecution or cruel and unusual treatment and entitle her to protection. Accordingly, when arrangements have been made for their removal, ${ }^{146}$ eligible persons are notified that they may apply for a PRRA. ${ }^{147}$ Protection claimants may only submit new evidence arising since the rejection of their claim by the RPD or evidence that was not reasonably available or that the claimant could not

(C) Gerald P. Heckman, 2008. This open-access work is licensed under a Creative Commons Attribution-NonCommercial 4.0 International License, which permits use, reproduction and distribution in any medium for non-commercial purposes, provided the original author(s) are credited and the original publication in Refuge: Canada's Journal on Refugees is cited. 
reasonably have been expected to have presented at the time of the rejection. ${ }^{148}$ In a PRRA, a public servant employed by CIC decides, based on a written application, whether the applicant has established that she comes within the Convention refugee definition or is a person in need of protection. ${ }^{149} \mathrm{~A}$ successful applicant receives refugee protection just as if the RPD had granted it. ${ }^{150}$ Unsuccessful applicants may seek leave to apply for judicial review of the PRRA decision.

At any time, refugee protection claimants may apply to remain in Canada on humanitarian and compassionate grounds. ${ }^{151}$ The IRPA confers on the Minister the discretion to grant any non-citizen permanent resident status or an exemption from any applicable statutory requirement if this is justified by public policy considerations or by humanitarian and compassionate considerations relating to the noncitizen, taking into account the best interests of a directly affected child. CIC has structured this ministerial discretion by requiring officers to take into account very detailed guidelines. ${ }^{152}$ Essentially, a H\&C applicant must show that requiring her to apply for permanent residence from outside of Canada would result in unusual and undeserved or disproportionate hardship. ${ }^{153}$ She may also claim that her removal from Canada would subject her personally to a risk to her life or security of the person. ${ }^{154}$ In such a case, the H\&C officer assesses all "non-risk" factors, approves the application if these are sufficient, and, if not, forwards it to a PRRA officer for a risk opinion which the $\mathrm{H} \& \mathrm{C}$ officer considers in accepting or rejecting the application. ${ }^{155} \mathrm{H} \& \mathrm{C}$ applications are typically "heard" on the papers. Filing an H\&C application does not stay a removal order. Claimants may seek leave to apply for judicial review of unfavourable $\mathrm{H} \& \mathrm{C}$ decisions.

\section{Review by the Federal Court of Canada}

A refugee protection claimant may contest an unfavourable eligibility decision, refugee protection decision, PRRA, or $\mathrm{H} \& \mathrm{C}$ decision by applying to the Federal Court in writing, within fifteen days of the decision, for leave to apply for judicial review. ${ }^{156}$ Leave applications are determined "without delay and in a summary way," 157 and granted only if the application discloses a fairly arguable case for the relief requested. ${ }^{158}$ Judges should not review the merits of the application for judicial review save to the extent required to deal with the leave application, ${ }^{159}$ and should not grant leave lightly since the leave stage is meant to screen out frivolous applications. ${ }^{160}$ Judges provide no written reasons in support of leave decisions, ${ }^{161}$ which are not subject to appeal. ${ }^{162}$ Between 2004 and 2007, the proportion of successful applications for leave and judicial review of refugee protection decisions ranged from 12 to 18 per cent. ${ }^{163}$

Judicial review is restricted to narrow grounds of review set out in the Federal Court Act. ${ }^{164}$ On successful applica- tions, the Court usually quashes the impugned decision and remits the protection claim to the decision maker for a determination in accordance with its directions. ${ }^{165}$ Unsuccessful applicants may appeal to the Federal Court of Appeal only if the trial judge hearing the judicial review application agrees to certify that "a serious question of general importance is involved." 166 Trial judges certify questions for appeal in exceptional circumstances, where the question is both serious and of general importance, would be determinative of the appeal, ${ }^{167}$ transcends the interests of the immediate parties, and contemplates issues of "broad significance and general application." 168 The decision not to certify a question cannot be appealed. Before the Court of Appeal, the appellant may advance grounds of appeal in addition to those pleaded in the certified question. ${ }^{169}$

To determine the intensity with which it should review determinations of the RPD or of a PRRA or H\&C officer, the Federal Court applies a "standard of review" analysis which requires it to consider whether the question raised by the legislative provision at issue in the particular case was intended by Parliament to be determined exclusively by the administrative decision maker. The standard of review depends on the presence of a privative clause in the decision maker's enabling statute, whether the decision maker has special expertise relative to courts in the matter under review, the purpose of the statutory provision at issue and the nature of the question to be decided (i.e., fact, law, mixed fact and law). ${ }^{170}$ Until recently, ${ }^{171}$ there were three possible standards of review. ${ }^{172}$ Under the "correctness" standard, courts owe no deference to a decision-maker's interpretations or determinations. In contrast, under the "patent unreasonableness" standard, courts deferred to a tribunal's determinations made in the heartland of its expertise unless these were clearly irrational. Under the intermediate "reasonableness" standard, courts intervene if the decision-maker's decision is "not supported by any reasons that stand up to a somewhat probing examination." ${ }^{173}$ The Supreme Court of Canada has now collapsed the patent unreasonableness and reasonableness standards into a single form of reasonableness review. However, this has not "pave[d] the way for a more intrusive review by the courts." 174 A deferential reasonableness standard will usually "apply automatically" where courts review questions of fact, discretion, or policy, or questions where legal and factual issues are intertwined. ${ }^{175}$

The Federal Court reviews RPD decisions on questions of law, including the interpretation of the Refugee Convention, on an exacting correctness standard, ${ }^{176}$ largely because the RPD enjoys no relative expertise in interpreting general legal principles that define basic human rights guarantees. In contrast, it accords the highest degree of deference to the RPD's determination of a claimant's credibility or of the plausibility 
of her evidence, which it judges to be "at the heartland of the discretion of triers of fact," 177 and to the RPD's appreciation and weighing of the evidence adduced before it. ${ }^{178}$ The Federal Court has stated that it would not set aside findings of fact unless they were patently unreasonable. Although the appropriate standard is now reasonableness, the Court still approaches the judicial review of RPD decisions with considerable deference. ${ }^{179}$ It also reviews PRRA decisions on a deferential standard of reasonableness, since they are based on an appreciation of new evidence and credibility, ${ }^{180}$ and applies the same standard of review to the discretionary and fact-intensive $\mathrm{H} \& \mathrm{C}$ decisions. ${ }^{181}$

Based on this brief description of Canada's refugee status determination system, the next section assesses whether refugee protection decision making in Canada conforms to the international norm of tribunal independence.

\section{The Independence of Canadian Refugee Protection Adjudicators}

As discussed above, to meet international norms of independence, disputes involving fundamental human rights that are adjudicated at first instance by a non-independent decision maker ${ }^{182}$ must be subject to more intense review by an independent court or administrative tribunal with sufficient jurisdiction over the merits-legal and factual-of the dispute. In Canada, judicial review of refugee protection decisions is available, with leave, in the Federal Court-an independent tribunal. However, the small proportion of refugee protection claimants who obtain leave to apply for judicial review are heard by a court that may not have sufficient jurisdiction over the merits of refugee protection decisions because it conducts a very deferential review of the factual determinations of first instance refugee protection decision makers, including the RPD and PRRA officers, applying deferential standards of "no evidence," unreasonableness or irrationality. ${ }^{183}$ Considering the fundamental rights at stake in refugee protection decisions, such deferential judicial review, especially of factual findings, may not be intense enough to satisfy international standards, particularly as elaborated by the European Court in Bryan and by the House of Lords in Alconbury and Begum. Consequently, the right of refugee protection claimants to a hearing of their claim by an independent tribunal will be respected only if the first instance decision maker or any merits review tribunal meets the requirements of tribunal independence.

Depending on the circumstances under which a protection claim is brought in Canada, it may be considered at first instance by the RPD, a PRRA officer, or an immigration officer. The RPD likely meets international norms of independence. However, there exist serious concerns about the independence of officers charged with pre-removal risk assessments of ineligible protection claimants, and border services officers responsible for deciding whether claimants arriving via the United States are eligible for a protection hearing in Canada under the safe third country agreement are probably not sufficiently independent. These concerns have also been voiced by international treaty bodies. ${ }^{184}$

\section{Protection Decisions by the Refugee Protection Division}

The RPD would probably be recognized as an independent tribunal under international law. Established by the IRPA, it has full jurisdiction to hear and determine all questions of law and fact in refugee protection proceedings. Its members benefit from strong guarantees of security of tenure. Appointed for relatively lengthy fixed terms, they are virtually irremovable. ${ }^{185}$ They enjoy financial security, receiving a remuneration fixed by the Governor-in-Council. ${ }^{186}$ The IRPA vests administrative control in the IRB Chair, who is empowered to supervise and direct IRB staff, assign administrative duties to members, apportion work among members, and guide members' decision making by issuing written guidelines and identifying specific IRB decisions as jurisprudential guides. ${ }^{187}$ Though further research is needed to assess the impact of recent controversial changes to the appointment process for RPD members, ${ }^{188}$ an RPD proceeding likely constitutes a hearing before an independent tribunal. ${ }^{189}$

\section{Protection Decisions by PRRA officers}

Some refugee protection claims are ineligible for a hearing by the RPD and are considered on the merits in a pre-removal risk assessment by a PRRA officer. PRRA officers are public servants employed by CIC. Their status and the significant impact of their decisions on non-citizens' lives raise concerns about whether they are sufficiently independent from the executive. The Federal Court of Appeal discussed similar concerns under earlier immigration legislation in Mohammad v. Canada (M.E.I.). ${ }^{190}$ Mohammad claimed that immigration adjudicators who conducted deportation inquiries lacked the institutional independence required by common law natural justice and section 7 of the Charter. Adjudicators were ordinary public servants employed by the Canada Employment and Immigration Commission (CEIC). Along with case presenting officers, who were part of the Enforcement Branch, they fell under the same associate deputy minister and were advised by the same Legal Services Branch. They were sometimes seconded to enforcement positions and case presenting officers were sometimes assigned to be adjudicators. The motions judge held that the relatively low independence level of adjudicators was acceptable because their decisions could be appealed to the more independent Immigration Appeals Tribunal, ${ }^{191}$ and from there to the Federal Court of Appeal. ${ }^{192}$ The Court of Appeal agreed that adjudicators 
had sufficient institutional independence having regard to the statutory scheme, the regulations, administrative directives, job descriptions, and the sworn testimony of a former adjudicator regarding the operation of the adjudication system. ${ }^{193}$ It noted that adjudicators and case presenting officers de facto operated within separate divisions of CEIC - the Adjudication Directorate and the Enforcement Branch-and did not report to a common superior. Seconding staff from one division to the other did not undermine this institutional separation. With appropriate safeguards, which included placing adjudicators within a directorate autonomous from enforcement staff, ensuring that they had recourse to public service grievance procedures, specifying in administrative directives and job descriptions that their independence had to be respected, and requiring them to swear an oath to faithfully and honestly fulfil their duties as public servants, the adjudication of immigration matters by public servants complied with the right to be heard by an independent tribunal.

While Mohammad indicates that PRRA officers may be independent under Canadian law, there are signs that this decision no longer reflects Canadian or international standards of independence. Marked by internal inconsistencies, ${ }^{194}$ the judgment was largely displaced by 1993 amendments to the Immigration Act that created an Adjudication Division within the IRB, ${ }^{195}$ provided for the appointment of adjudicators under the Public Service Employment Act, and ensured that they reported to the IRB Chair, not the Minister. ${ }^{196}$ The Federal Court of Appeal questioned Mohammad's validity in Ahumada v. Canada (M.C.I.), where it held that the secondment of an enforcement officer to the Convention Refugee Determination Division (CRDD) of the IRB raised a reasonable apprehension of bias, because she might "be mindful" of how her colleagues in CIC's enforcement branch would view her decisions and their effect on her career at CIC. ${ }^{197}$ Mohammad, it held, predated several Supreme Court cases in which statutory schemes of administrative adjudication had been impugned for failing to ensure institutional independence and may not have been decided the same way today "as it was nearly 15 years ago." 198 The Court warned that "officials responsible for enforcing the law ... almost inevitably tend to view matters from an enforcement perspective" and observed that in order to avoid the danger of enforcement-minded adjudication, the Immigration Act "entrusts adjudicative functions to a tribunal that is independent of, and separate from, the agency responsible for enforcement." 199 Even after the 1993 amendments, the Inter-American Commission on Human Rights expressed concern over the lower level of independence enjoyed by adjudicators, and the Adjudication Division's enforcement focus, given the grave impact of adjudicators' decisions on protection claimants. $^{200}$
Unsuccessful PRRA applicants have claimed that PRRA officers lack institutional independence and that their determinations therefore breach common law procedural fairness or the principles of fundamental justice under section 7 of the Charter. ${ }^{201}$ Many such claims were filed following a short-lived 2003 transfer of PRRA officers along with those portions of CIC offices in Canada that dealt with enforcement to the newly created CBSA, reporting to the Minister of Public Safety and Emergency Preparedness (PSEP). ${ }^{202}$ The government's decision to group PRRAs with enforcement functions including removals, detention and investigation raised the eyebrows of refugee advocates, who questioned whether the CBSA, whose primary mandate was enforcement and border control, could credibly protect refugees. ${ }^{203}$ Within ten months, the government had returned the PRRA function to CIC because it was "more closely aligned with the protection aspect of CIC's mandate." ${ }^{204}$ Viewed charitably, the transfer of PRRAs to the CBSA was simply a mistake. It could also signal that the Canadian government considered PRRAs to be part of the enforcement and removal process, and cast a shadow over the independence of PRRA officers before December 2003, when they reported to a CIC whose responsibilities included enforcement, ${ }^{205}$ and when they subsequently reported to the CBSA, an enforcement and intelligence agency. Conversely, their current placement within a CIC shorn of some of its enforcement functions may enhance their institutional independence.

In Say v. Canada, ${ }^{206}$ the Federal Court rejected the claim that PRRA officers, when they worked within the CBSA, were "supervised and controlled by officials whose interest it is to remove the people whose cases they are assessing" and thus lacked institutional independence. ${ }^{207}$ In response to this claim, the federal government argued that it deliberately safeguarded PRRA officers' independence by physically and operationally insulating them from immigration enforcement functions and by training them about the importance of independence. ${ }^{208}$ Removal officers from the CBSA's enforcement unit, who provide removal-ready individuals with PRRA applications, must coordinate their efforts with the PRRA units to ensure that individual files flow to the PRRA unit for a risk assessment and back to the CBSA for removal arrangements, depending on the outcome of the assessment. To allow this interaction without jeopardizing the independence of the PRRA officers, ${ }^{209} \mathrm{CIC}$ entrusted coordination functions to "PRRA Coordinators" who act as a "firewall" between the PRRA officers and the enforcement unit. PRRA Coordinators do not conduct risk assessments but assign applications to individual officers for decision, hire PRRA officers, and evaluate their job performance based on the quality of their written decisions and on their productivity. PRRA officers are instructed not to have direct contact with 
removals or enforcement personnel. ${ }^{210}$ They may seek guidance and policy advice regarding their substantive decisionmaking duties from the National PRRA Policy Unit in CIC's Refugees Branch. ${ }^{211}$ This institutional separation between PRRA officers and enforcement personnel is reinforced by the practice of housing PRRA units in physically separate offices $^{212}$ and providing them with dedicated administrative support. ${ }^{213}$ Together with the fact that PRRA Coordinators, not the enforcement unit, assign files to individual officers, these factors may establish a relatively high degree of administrative control. ${ }^{214}$ Moreover, the government argued, PRRA officers enjoy sufficient security of tenure and remuneration to guarantee their independence because most hold permanent positions within the public service. ${ }^{215}$ Finally, they receive training on administrative law and the importance of independence. ${ }^{216}$ In Say, the Federal Court found the government's arguments convincing. It concluded that there would not be a reasonable apprehension of bias, in the mind of a fully informed person, in a substantial number of cases, because "there was a conscious effort to insulate the PRRA Program from the enforcement and removal functions of the CBSA."217

Since, as the federal government concedes, the requisite level of independence depends in part on the interests at stake in the decision-making process, ${ }^{218}$ it is noteworthy that under the former Immigration Act, failed refugee claimants could obtain additional hearings before the CRDD if they re-entered Canada more than six months after the last determination. Under the IRPA, claimants are entitled to only one hearing before the RPD, but to multiple PRRA hearings following the RPD's dismissal of their claim. PRRA officers have assumed a role once played by an independent tribunal; they make risk determinations of a similar nature and apply the same definition of "person in need of protection." A positive PRRA decision earns claimants protection similar to that granted by the RPD to successful refugee claimants. Based strictly on the nature of the individual interests at stake, then, PRRA officers should meet the same independence standards as RPD members. They do not. Whether the measures adopted by CIC to shield them from enforcement influence suffice to guarantee their independence is debatable. Although the unionized regime governing the employment of most public servants, including the grievance process, does provide some measure of employment security, these protections appear to fall short of standards recognized by the European Court. ${ }^{219}$ Public servants are vulnerable to the influence of potentially careerlimiting evaluations. ${ }^{220}$ They could be expected, as noted in Ahumada, to be "mindful" of the impact of their decisions on their advancement prospects in government, including departments linked to immigration enforcement.
In Say, the Federal Court held that in assessing whether the grounds for the perception of a lack of institutional independence are "substantial" enough, it would show substantial deference to government decisions "that relate to appropriate organization of public servants devoted to the administration of the vast range of responsibilities of the Government of Canada."221 The court's deferential posture in assessing the institutional independence of PRRA officers is inappropriate. PRRA officers are public servants, but they have extraordinary responsibilities. They make decisions that engage refugee protection claimants' constitutionally protected life and security of the person interests. Their institutional independence should be re-evaluated in light of this reality. ${ }^{222}$

\section{Eligibility Determinations by Immigration Officers}

Immigration officers determine whether refugee protection claimants are eligible to have their protection claims heard by the RPD. At ports of entry, they are public servants employed by the CBSA, an agency primarily concerned with immigration law enforcement. Inland, they are public servants employed by CIC. Without additional guarantees, these officers cannot be considered independent from the executive. In most circumstances, their lack of independence does not necessarily result in a violation of protection claimants' right to have their claims assessed by an independent tribunal, since eligibility determinations are usually followed by a risk assessment by a PRRA officer, who may be independent. Claimants found to be ineligible because they came to Canada from a country designated as a safe country do not receive a PRRA. ${ }^{223}$ In 2007, the Federal Court determined that returning asylum seekers to the United States under the Safe Third Country Agreement infringed their fundamental Charter rights because many aspects of the US refugee status determination system do not live up to international norms. ${ }^{224}$ If this were indeed the case, because ineligible claimants are not entitled to a PRRA, eligibility determinations engage their life and security of the person interests and must conform to the principles of fundamental justice. Fundamental justice and international norms would require that independent and impartial decision makers afford the claimants a hearing and assess whether their life or freedom would be threatened upon their return to the United States. The officers who interview claimants at the border, make eligibility decisions and review their colleagues' decisions are employed by the CBSA, an agency tasked with the enforcement of Canada's immigration laws. They do not make decisions following the quasi-judicial process and with the accompanying safeguards contemplated by the European Court in Bryan. Although their decisions are open to judicial review, the proceedings as a whole would likely not consti- 
tute a hearing before an independent and impartial tribunal, particularly in light of the fundamental nature of the interests at stake. ${ }^{225}$

\section{Critiques of the Canadian System by Treaty Bodies}

Regional and international treaty bodies have criticized Canada's decision to entrust pre-removal risk assessment and eligibility decisions to government officials. In 2000, the Inter-American Commission on Human Rights reported on whether Canada's refugee determination process comported with its Inter-American human rights obligations. It interpreted the right to seek asylum in article XXVII of the American Declaration on the Rights and Duties of $\mathrm{Man}^{226}$ as requiring that each refugee claimant be "accorded the minimum guarantees necessary to effectively state his or her claim," 227 and voiced concern that non-independent immigration officials made eligibility and admissibility decisions:

\footnotetext{
Senior immigration officers are employees of ... [CIC]. Members of the Adjudication Division, while part of the IRB, are also public servants rather than appointed decision-makers. Further, while the CRDD has specialized expertise, procedures and resources for determining refugee claims, the Adjudication Division deals in broader terms and through adversarial procedures with who is admissible or removable from Canada, and with detention reviews. Because the mandate of the Adjudication Division is more heavily directed toward control issues and lawenforcement, it is inherently less able to properly balance the public and individual interests involved. ${ }^{228}$
}

It proposed that the independent CRDD decide eligibility and admissibility:

[T] he nature of the rights potentially at issue-for example, to life and to be free from torture-requires the strictest adherence to all applicable safeguards. Those safeguards include the right to have one's eligibility to enter the process decided by a competent, independent and impartial decision-maker, through a process which is fair and transparent. ${ }^{229}$

In its Concluding Observations on Canada's third periodic report regarding its implementation of its obligations under the 1984 UN Convention Against Torture and Other Cruel, Inhuman and Degrading Treatment or Punishment, ${ }^{230}$ and in particular the article 3(1) prohibition against refoulement to torture, the Committee Against Torture (CAT) expressed concerns that "the alleged lack of independence of decisionmakers," among other factors, could hinder the effectiveness of risk assessments in protecting claimants' rights under the CAT. ${ }^{231}$ Acknowledging Canada's assurances that the PRRA process proposed under the forthcoming IRPA would have an application broader than that of the old process, the Committee encouraged Canada "to ensure that IRPA permitted in-depth examination of claims by an independent entity ..."232 In its Concluding Observations on Canada's fourth and fifth periodic reports, the Committee recommended that Canada "provide for judicial review of the merits rather than merely the reasonableness" of decisions to expel noncitizens where article 3(1) CAT is engaged. ${ }^{233}$ It reiterated these concerns in its views on the petition of Enrique Falcon Ríos, a Mexican citizen who claimed to have been tortured by Mexican soldiers who suspected that he and his family were supporters of the Zapatista national liberation movement. ${ }^{234}$ The CRDD dismissed his refugee claim, finding that his account of the events leading to his flight from Mexico was not credible due in part to significant "gaps" in his testimony. ${ }^{235}$ The Federal Court dismissed Ríos's application for judicial review, finding no error that would justify its intervention. After he was refused permission to remain in Canada on humanitarian and compassionate grounds, he filed a petition arguing that he would be tortured if returned to Mexico. Canada argued that the petition was inadmissible because Ríos had not exhausted domestic remedies likely to bring effective relief, including judicial review of the negative $\mathrm{H} \& \mathrm{C}$ decision and a PRRA. The Committee disagreed, finding that for Ríos, neither an H\&C application nor a PRRA would effectively protect his rights under the CAT. Humanitarian and compassionate assistance, if granted, was on a purely discretionary basis, ${ }^{236}$ and there were significant concerns about how $\mathrm{H} \& \mathrm{C}$ officers' lack of independence could jeopardize the effectiveness of $\mathrm{H} \& \mathrm{C}$ applications as a remedy against refoulement. ${ }^{237}$ A PRRA would not have been effective, since the PRRA officer could only have considered fresh evidence arising after the initial CRDD decision and Ríos was really seeking a rehearing of his case. ${ }^{238}$ The Committee allowed the petition. ${ }^{239}$ In subsequent petitions brought before the Committee, Canada has claimed that Ríos was wrongly decided and has argued, relying on Say, that the PRRA process is an effective remedy because PRRA officers are specially trained to consider provisions of the Canadian Charter and international human rights treaties and are independent and impartial, and because it is "governed by statutory criteria for protection, conducted pursuant to a highly regulated process and in accordance with extensive and detailed guidelines" and is subject to judicial review. ${ }^{240}$ The Committee appears to have backed down from its critical position in Ríos, finding in several cases that, on their specific facts, the PRRA process combined with judicial review had constituted an effective remedy. ${ }^{241}$

In sum, because of the Federal Court's limited jurisdiction in judicial review proceedings over the merits of refugee protection claims, international norms of independence would 
require administrative decision makers who make final decisions on the merits of protection claims to be independent. While the RPD is likely independent, the status of PRRA officers as civil servants within CIC raises some concerns about their independence. Protection claimants who can establish that they will likely be deprived of a fair hearing of their claims and exposed to refoulement if returned to the United States under the Safe Third Country Agreement are entitled under international norms to a hearing of their claim before an independent tribunal. The CBSA officers responsible for determining their eligibility to a hearing before the RPD are part of Canada's border control machinery and are not sufficiently independent. The concerns over the independence of PRRA officers and immigration officers are echoed in the reports and jurisprudence of regional and international treaty bodies. Because judicial review of their decisions is not available as of right and since, in the small proportion of cases where leave is granted, reviewing courts apply deferential standards of review on questions of fact and credibility, refugee protection decision making by immigration officers and PRRA officers may not meet international standards of independence.

\section{Conclusion}

I have argued, based on a review of the jurisprudence developed under the ICCPR and ECHR, that article 14 of the ICCPR guarantees refugee protection claimants a hearing of their protection claims before an independent tribunal with sufficient jurisdiction over the merits of these claims. In certain cases, the administrative decision makers responsible for the adjudication of refugee protection claims in Canada are not sufficiently isolated from the influence of the executive arm of government responsible for the enforcement of ordinary immigration laws. Where, in these circumstances, refugee protection claimants succeed in obtaining leave to apply for judicial review, the Federal Court's deferential review of questions of fact and credibility means that the Court does not have sufficient jurisdiction over the merits of protection claims as required by the international norm of tribunal independence.

How should Canada's Parliament and judiciary respond to such gaps between Canadian refugee protection laws and international human rights norms? In contemplating reforms to Canada's refugee protection system, legislators should harmonize it with international human rights norms and, at the very least, reject proposed changes that would widen the gap between domestic and international law. Canadian legislators showed openness to the positive influence of international human rights law when they inserted in the IRPA a requirement that its provisions be interpreted and applied in a manner that complies with international human rights instruments to which Canada is a signatory. ${ }^{242}$ If Canada's Parliament fails to align Canada's refugee protection system with international standards, then refugee protection claimants may have little choice but to ask domestic courts to address the existing gaps through constitutional challenges. I have argued elsewhere ${ }^{243}$ that Canadian courts should recognize that human rights norms expressed in ratified international treaties are prima facie evidence of the existence of similar or identical fundamental norms in Canadian law, and that they are therefore bound to interpret the Charter (including the content of fundamental justice-the source of refugee protection claimants' entrenched constitutional procedural and institutional rights) in conformity with these treaty norms, absent evidence that they are not universal in nature or lack resonance with Canadian legal values. At present, however, the Supreme Court has not clearly held that it is under a legal duty to interpret the Charter in conformity with Canada's international human rights obligations-only that there exists a "rule of judicial policy" that it should do so. ${ }^{244}$

Could refugee protection claimants persuade Canadian courts to invalidate Canada's refugee protection laws because they conflict with principles of fundamental justice shaped by Canada's international human rights obligations, including the international norm of tribunal independence? Clearly, significant obstacles must be overcome before such challenges could succeed. But at the very least, international human rights norms, forged from a broad consensus among disparate nations, provide an important measuring rod with which to assess the scope and content of procedural and institutional safeguards, including tribunal independence, in domestic refugee protection systems. Gaps between domestic protections and international standards need to be identified and, if possible, justified. The analytical framework I have developed here is a first step in this larger project.

\section{Notes}

1. Singh v. Canada (Minister of Employment and Immigration), [1985] 1 S.C.R. 177 [Singh].

2. C. Clark, "Critics assail Coderre's proposals for refugee system" The Globe and Mail (21 March 2003) A15.

3. "Refugee backlog headed for record high as Tories slow to appoint adjudicators" Canadian Press (8 April 2008).

4. 19 December 1966, 999 U.N.T.S. 171, Can. T.S. 1976 No. 47 [ICCPR or Covenant].

5. 4 November 1950, 213 U.N.T.S. 221, Eur. T.S. 5, art. 6 [ECHR or European Convention].

6. GA Res. 217(III) UN GAOR, 3d Sess., Supp. No. 13, UN Doc. A/810 (1948) 71, art. 10 [UDHR or Declaration].

7. 22 November 1969, 65 A.J.I.L. 679, art. 8.

8. Commission on Human Rights, Sub-Commission on Prevention of Discrimination and Protection of Minorities,

(C) Gerald P. Heckman, 2008. This open-access work is licensed under a Creative Commons Attribution-NonCommercial 4.0 International License, which permits use, reproduction and distribution in any medium for non-commercial purposes, provided the original author(s) are credited and the original publication in Refuge: Canada's Journal on Refugees is cited. 
Independence and Impartiality of the Judiciary, Jurors and Assessors and the Independence of Lawyers-report by the Special Rapporteur Param Cumaraswamy, UN Doc. E/ CN.4/1995/39 (1995) at para. 35.

9. R. v. Hape, 2007 SCC 26 at paras. 53 and 54 [Hape].

10. Canadian Charter of Rights and Freedoms, Part I of the Constitution Act, 1982 being Schedule B to the Canada Act 1982 (U.K.), 1982, c. 11 [Charter]. Presenting Canada's fourth periodic report regarding the ICCPR's implementation to the UN Committee on Human Rights, Canada's representative stated that the Charter "was the primary mechanism" for implementing the ICCPR and that the Charter's provisions "were based on the Covenant": UN Human Rights Committee, Summary Record of the $1738^{\text {th }}$ Meeting: Canada (17 March 1999), UN Doc. CCPR/C/SR.1738, online: <http://www.unhchr.ch> (date accessed: 15 February 2005).

11. Optional Protocol to the International Covenant on Civil and Political Rights, 16 December 1966, 999 U.N.T.S. 171, Can. T.S. 1976 No. 47 [“Optional Protocol”].

12. Committee on Human Rights, Communication No. 1234/2003, P.K. v. Canada, UN Doc. CCPR/ C/89/D/1234/2003 (3 April 2007) [P.K.].

13. Maaouia v. France (2001) 33 E.H.R.R. 42 [Maaouia].

14. See Gerald Heckman, "International Law and Procedural Safeguards in Deportation Proceedings: Ahani v. Canada" (2004) 17.2 R.Q.D.I. 81 at 102 [Heckman, Deportation].

15. See D. Weissbrodt, The Right to a Fair Trial under the Universal Declaration of Human Rights and the International Covenant on Civil and Political Rights (The Hague: Kluwer Law International, 2001) at 46, 48 and 51; P. van Dijk, "The interpretation of civil rights and obligations" by the European Court of Human Rights-One more step to take" in F. Matscher \& H. Petzold, eds, Protecting Human Rights: The European Dimension-Studies in Honour of Gérard Wiarda, 2d ed. (Carl Heymans Verlag KG: Berlin, 1990) 131 [van Dijk 1990].

16. Weissbrodt, supra note 15 at 51 . Roosevelt had expressed concern that administrative officers, not courts, determined many civil rights obligations like those connected with military service and taxation. van Dijk observes that these particular "civil rights and obligations" were not of a private law character, and concludes that Roosevelt understood "civil" to include all non-penal or non-criminal matters rather than solely private law matters: van Dijk 1990, supra note 15 at 137 .

17. Van Dijk, ibid. at 137.

18. Weissbrodt, supra note 15 at 51 .

19. Committee on Human Rights, Communication No. 112/1981, Y.L. v. Canada, UNGAOR, $41^{\text {st }}$ Sess., Supp. No. 40, UN Doc. A/41/40 (1986) at 145 [Y.L.].

20. Ibid. at para. 9.2.

21. Ibid. at para. 9.4 .

22. Ibid. at paras 9.4-9.5.
23. For a detailed discussion, see Heckman, Deportation supra note 14 at 107.

24. Weissbrodt, supra note 15 at 139; S. Bailey, "Rights in the Administration of Justice" in D. Harris \& S. Joseph, eds, The International Covenant on Civil and Political Rights and United Kingdom Law (Oxford: Clarendon Press, 1995) at 212; D.J. Harris, Cases and Materials on International Law, 5th ed. (London: Sweet and Maxwell, 1998) at 672; D. McGoldrick, The Human Rights Committee (Oxford: Clarendon Press, 1991) at 416. See also P. Boeles, Fair Immigration Proceedings in Europe (The Hague: Martinus Nijhoff, 1995) at 137; S. Joseph et al., The International Covenant on Civil and Political Rights: Cases, Materials and Commentary (Oxford: Oxford University Press, 2000) at 281.

25. Committee on Human Rights, Communication No. 441/1990, Casanovas v. France, 1994, UN Doc. CCPR/ C/51/D/441/1990 at paras. 5.2 and 7.4. See also Communication No.454/1991, Pons v. Spain, 1995, UN Doc. CCPR/ C/55/D/454/1991, at para. 9.6.

26. Committee on Human Rights, Communication No. 1052/2002, Tcholatch v. Canada, 2007, UN Doc. CCPR/ $\mathrm{C} / 89 / \mathrm{D} / 1052 / 2002$.

27. Committee on Human Rights, Communication No. 972/2001, Kazantzis v. Cyprus, 2003, UN Doc. CCPR/ C/78/D/972/2001, at para. 6.5.

28. See D. Mullan, Administrative Law (Toronto: Irwin Law, 2001) at 100-102.

29. See in particular, Baker v. Canada (Minister of Citizenship and Immigration), [1999] 2 S.C.R. 817 at paras. 23-25 [Baker].

30. Kaplan, Report of 17 July 1980, (1981) D\&R 21 at 5(21).

31. See Skärby v. Sweden (1990), 13 E.H.R.R. 90 at para. 28: a dispute over a right arises where the applicant can arguably claim that the state authority has exercised its statutory discretion in a manner contrary to generally recognized legal and administrative principles. See also P. van Dijk \& G.J.H. van Hoof, Theory and Practice of the European Convention on Human Rights (The Hague: Kluwer Law, 1998) at 395.

32. Benthem v. Netherlands (1986) 8 E.H.R.R. 1 [Benthem].

33. Van Dijk 1998, supra note 31 at 397. For example, disciplinary proceedings against a doctor, although designed primarily to protect patients and promote public confidence in the medical profession, had a sufficient impact on the doctor's right to practice his profession that it effectively determined this "civil" right: Le Compte, Van Leuven and De Meyere v. Belgium (1981), 4 E.H.R.R. 1 at paras. 47-8 [Le Compte].

34. Van Dijk 1998, ibid. at 392-4; see also van Dijk 1990, supra note 15.

35. This view is set out convincingly in the dissenting opinion of Judge Loucaides in Maaouia, supra note 13 at O-IV3-8.

36. Benthem, supra note 32 at para. 34 .

37. Tre Traktörer Aktiebolag v. Sweden (1989), 13 E.H.R.R. 309 at para. $42-43$. The permit conferred "civil" rights because 
it was essential for the applicant to carry on its business activities as a restaurant.

38. Le Compte, supra note 33.

39. Feldebrugge v. Netherlands (1986), 8 E.H.R.R. 425 at para. 40. The Court emphasized the public health insurance's private law features, including its resemblance to private insurance, the tie between the availability of benefits and the applicant's employment under a private law contract, and the personal, economic, and individual nature of the right, of crucial importance to a person who by reason of illness has no other source of income. These "confer[red] on the asserted entitlement the character of a civil right ..."

40. Salesi v. Italy (1993), 26 E.H.R.R. 187 [Salesi]. This time, the Court did not rely on similarities between the statutory welfare assistance program and private schemes, but on the fact that Salesi suffered an interference with her means of subsistence and was claiming an individual, economic right flowing from specific rules laid down in a statute giving effect to the Constitution. See also Schuler-Zgraggen v. Switzerland (1993) 16 E.H.R.R. 405 at para. 46. The European Court has recently further broadened the scope of art. 6(1) in Vilho Eskelinen v. Finland, no. 63235/00 (19 April 2007) [Vilho Eskelinen].

41. UNHCR, Handbook on Procedures and Criteria for Determining Refugee Status (1992), para. 28.

42. James C. Hathaway, The Rights of Refugees under International Law (Cambridge: Cambridge University Press, 2005) at 158.

43. These include: rights to acquire, lease, or otherwise contract in respect of movable and immovable property and intellectual property rights: Convention relating to the Status of Refugees, 28 July 1951, 189 U.N.T.S. 2545, Can. T.S. 1969/6, arts. 13, 14 [Refugee Convention].

44. Kraska v. Switzerland (1993), 18 E.H.R.R. 188.

45. Refugee Convention, supra note 43 , art. 23.

46. Defined as "legal provisions in respect of employment injury, occupational diseases, maternity, sickness, disability, old age, death, unemployment, family responsibilities and any other contingency which, according to national laws or regulations, is covered by a social security scheme": ibid., art. 24(1)(b).

47. Recognition of refugee status is thus a necessary precondition to the exercise of the civil rights expressed in the Refugee Convention, even if it may not be sufficient, since many of these rights apply only once a refugee attains a specific level of attachment to the asylum state, usually ranging from physical presence to lawful presence and finally, to durable residence: Hathaway, supra note 42 at 156 et seq.

48. Maaouia, supra note 13 at para. 40.

49. Ibid. at paras. $38-39$.

50. The Court relied on "an explanatory report" on the protocol which noted that the protocol "did not affect" the European Commission's interpretation of art. 6 denying that it applied to deportation proceedings: ibid. at paras. 35-37.

51. Vilho Eskelinen, supra note 40 at para. 61.
52. Van Dijk 1990, supra note 15; Maaouia, supra note 13 at paras. O-IV4-O-IV11.

53. Maaouia, ibid. at para. O-IV7.

54. Ibid.

55. Ibid. at para. O-IV7.

56. Ibid. at O-IV15-O-IV17.

57. As the dissenting judges put it: "Protocols add to the rights of the individual. They do not restrict or abolish them": ibid. at para. O-IV14.

58. See also H. Steenbergen, P. Boeles, \& C. Wijnakker, "Case reports of the European Court of Human Rights" (2001), 3 Eur. J. Migr. \& L. 97 at 101.

59. Art. XVIII of the American Declaration of the Rights and Duties of Man, 2 May 1948, 43 A.J.I.L. 133 simply provides that "every person may resort to the courts to ensure respect for his legal rights." Similarly, art. 8(1) of the American Convention on Human Rights, 22 November 1969, 65 A.J.I.L. 679 extends the right to a hearing to "the determination of his rights and obligations of a civil, labor, fiscal, or any other nature." They are broad enough to extend the independence guarantee to refugee status determination or removal proceedings.

60. Supra note 12.

61. Art. 13 states: "An alien lawfully in the territory of a State Party to the present Covenant may be expelled therefrom only in pursuance of a decision reached in accordance with law and shall, except where compelling reasons of national security otherwise require, be allowed to submit the reasons against his expulsion and to have his case reviewed by, and be represented for the purpose before, the competent authority or a person or persons especially designated by the competent authority."

62. P.K., supra note 12 at para. 4.9 .

63. Ibid. at para. 7.5.

64. Human Rights Committee, Communication No. 1051/2002, Ahani v. Canada, 2004, UN Doc. CCPR/C/80/D/1051/2002 at para. 10.5 .

65. Refugee determinations do not always occur in the context of an expulsion, to which Protocol 7 and art. 13 are limited: Peter Billings, "The Influence of Human Rights Law on the Procedural Formalities of the Asylum Determination Process" (1998) 2 Int'l J.H.R. 32 at 38. But see Christian Tomuschat, "A Right to Asylum in Europe" (1992) 13 H.R.L.J. 257 at 263.

66. For a more detailed discussion of the scope and content of art. 13 ICCPR, see Heckman, Deportation, supra note 14.

67. M. Nowak, U.N. Covenant on Civil and Political RightsCCPR Commentary (Kehl am Rhein: N.P. Engel, 1993) at 244-5. A tribunal "established by law" is one whose jurisdiction, both in relation to subject matter and territorial application, is "determined generally and independently of the given case" rather than set arbitrarily by administrative fiat.

68. Committee on Human Rights, General Comment 13/21, Procedural Guarantees in Civil and Criminal Trials, UN- 
GAOR, $21^{\text {st }}$ Sess., Supp. No. 40, UN Doc. HRI $\backslash G E N \backslash I \backslash$ Rev.1 (1984) at para. 3.

69. See R. Brody, "Introduction" in R. Brody, ed., C.I.J.L. Bulletin No. 25-26, Special Issue-The Independence of Judges and Lawyers: A Compilation of International Standards (Geneva: Centre for the Independence of Judges and Lawyers, 1990) at 3-13 [C.I.J.L Special Bulletin].

70. United Nations Basic Principles on the Independence of the Judiciary, in C.I.J.L Special Bulletin, supra note 69 at 14 [Basic Principles].

71. A/RES/40/146/13 Dec. 1985. To encourage states to give effect to these basic principles, the UN Economic and Social Council adopted "Procedures for the Effective Implementation of the Basic Principles on the Independence of the Judiciary," a document also endorsed by the General Assembly: Res. 44/162/ 15 Dec. 1989.

72. E/CN.4/Sub.2/1988/20/Add.1 [Singhvi Declaration] in C.I.J.L Special Bulletin, supra note 69 at 38.

73. See, in particular, Valente v. The Queen, [1985] 2 S.C.R. 673 [Valente] and Canadian Pacific v. Matsqui Indian Band [1995] 1 S.C.R. 3. Art. 11 of the Basic Principles, supra note 70 provides that "the terms of office of judges, their independence, security, adequate remuneration, conditions of service, pensions and the age of retirement shall be adequately secured by law." See also Singhvi Declaration, ibid., art. 18. Art. 12 of the Basic Principles mandates guaranteed tenure until a fixed retirement age or the expiry of the judge's term in office: see also Singhvi Declaration, art. 16. The discipline, suspension, and removal of judges is strictly limited: Basic Principles, arts. 17-20; Singhvi Declaration, arts. 26-31. Art. 14 of the Basic Principles reserves to the judiciary the task of assigning individual cases to judges; see Singhvi Declaration, arts. 32-36. Art. 32 of the Singhvi Declaration confers on the judiciary or a body on which the judiciary is represented responsibility for court administration and court staff.

74. See Basic Principles, supra note 73, arts. 10 and 13; Singhvi Declaration, supra note 73, arts. 11 and 24.

75. Commission on Human Rights, Sub-Commission on Prevention of Discrimination and Protection of Minorities, The Administration of Justice and the Human Rights of Detainees: Study on the Independence and Impartiality of the Judiciary, Jurors and Assessors and the Independence of Lawyers-Final report by the Special Rapporteur, Mr. L. M. Singhvi, UN Doc. E/CN.4/Sub. 2/1985/18 (1985) at para. 108 [Singhvi final report].

76. Ibid. at para. 11 .

77. Ibid. at para. 14 .

78. Ibid. at paras. 13,14 .

79. Committee on Human Rights, Communication No. 468/1991, Bahamonde v. Equatorial Guinea, 49th Sess., UN Doc. $49 / 40$ (1993) at para. 9.4; Concluding Observations of the Human Rights Committee: Belarus, UN Doc. CCPR/C/79/Add.86 (1997) at paras. 13-14; Romania, UN Doc. CCPR/C/79/Add.111 (1999) at para. 10; Congo, UN
Doc. CCPR/C/79/Add.118 (2000) at para. 14; Sudan, UN Doc. CCPR/C/79/Add.85 (1997) at para. 21; Lithuania, UN Doc. CCPR/C/79/Add.87 (1997) at para. 16.

80. To be recognized as a tribunal under art. 6 , the decisionmaking body's function must be to "determine matters within its competence on the basis of rules of law, following proceedings conducted in a prescribed manner": Sramek $v$. Austria (1985) 7 E.H.R.R. 351 at para. 36. It must have a power of binding decision in its area of jurisdiction over questions of fact and law: Campbell and Fell v. U.K. (1984) 7 EHRR 165 at 198 [Campbell and Fell]; Le Compte, supra note 33 at para. 51. But see Bryan v. U.K. (1995), 21 E.H.R.R. 342 [Bryan]. It need not be "a court of law of the classic kind, integrated within the standard judicial machinery of the country": Campbell and Fell at para. 76.

81. Crociani v. Italy (1980) 22 D.R. 147 at para. 8 (Eur. Comm. H.R.) at 221, para. 10; Campbell and Fell, supra note 80 at para. 78.

82. Kleyn v. Netherlands (2004) 38:14 E.H.R.R. 239 at para. 193 [Kleyn].

83. In relation to the separation of legislative and judicial powers, see Stran Greek Refineries and Stratis Andreadis $v$. Greece, (1994) 19 E.H.R.R. 293 and McGonnell v. United Kingdom, (2000) 30 E.H.R.R. 289. Regarding the separation of executive and judicial powers, see Easterbrook v. United Kingdom, (2003) 37:40 E.H.R.R. 812.

84. Campbell and Fell, supra note 80 at para. 79 .

85. Ettl v. Austria (1987) 10 E.H.R.R. 255 at para. 38 [Ettl]; see also Stallinger v. Austria (1997) 26 E.H.R.R. 81.

86. Ettl, supra note 85 at paras. 20 and $40-41$. In these circumstances, the Court noted, it was appropriate for Austria to rely on civil servants with expertise in the complex field of land consolidation.

87. For example, while the three-year term of members of the Board of Visitors in Campbell and Fell was relatively short, the Court allowed for the fact that they were unpaid, and might refuse longer appointments: Campbell and Fell, supra note 80 at 199 , paras. $79-80$.

88. Campbell and Fell, supra note 80 at para. 80 .

89. Morris v. United Kingdom (2002) 34 E.H.R.R. 52 at paras. 68-9.

90. Ibid. at para. 72 .

91. Cooper v. United Kingdom, (2003) 39 E.H.R.R. 8.

92. Ibid. at para. 124 .

93. Ibid.

94. Ibid. at para. 125 .

95. Campbell and Fell, supra note 80 at paras. 81-82.

96. Bryan, supra note 80 at para. 38 .

97. Le Compte, supra note 33 at para. 51.

98. The Human Rights Committee has also held that an appellate hearing before a tribunal that complies with article 14(1) may cure the defects of an initial hearing before a non-compliant tribunal: Committee on Human Rights, Communication No. 387/1989, Karttunen v. Finland, 46th Sess., UN Doc. 46/40 (1992) at paras. 7.2-7.3. 
99. See Mark Poustie, "The Rule of Law or the Rule of Lawyers? Alconbury, Article 6(1) and the Role of Courts in Administrative Decisionmaking" (2001), 6 E.H.R.L.R. 657 at 663.

100. Albert and Le Compte v. Belgium (1983) 5 E.H.R.R. 533 at 541-2 [Albert and Le Compte].

101. Le Compte, supra note 33 at para. 51. The European Court has refused to apply the composite approach to exempt first instance trial courts hearing criminal charges from full compliance with all art. 6(1) requirements: De Cubber $v$. Belgium (1985) 7 E.H.R.R. 236 at para. 32.

102. W v. U.K. (1987), 10 E.H.R.R. 29; O v. U.K. (1987), 10 E.H.R.R. 82; B v. U.K. (1987), 10 E.H.R.R. 87; and R v. U.K. (1987), 10 E.H.R.R. 74.

103. B v. U.K., ibid. at para. 82. It was common ground that the proceedings before the local authorities did not satisfy art. $6(1)$.

104. Ibid. at paras. 49 and 82 . The Court could set aside a care order if, in making its decision, the local authority: acted illegally, ultra vires, or in bad faith; failed to consider relevant considerations, took into account irrelevant considerations, or came to a decision that no reasonable authority could have made (the standard of Wednesbury unreasonableness); or failed to act fairly or to observe statutory procedural rules.

105. For a more detailed discussion of this subject, see Gerald Heckman \& Lorne Sossin, "How Do Canadian Administrative Law Protections Measure Up to International Human Rights Standards?" (2005) 50 McGill L.J. 193 at 225-233.

106. Bryan, supra note 80 at para. 45 . See also $R$. (on the application of Holding \& Barnes Plc) v. Secretary of State for the Environment, Transport, and the Regions [2001] H.R.L.R. 45 at para. 154 [Alconbury].

107.Zumtobel v. Austria, (1993), 17 E.H.R.R. 116 at para. 32 [Zumtobel]; see also ISKCON v. U.K. (Application No. 20490/92), March 8, 1994 at para. 4.

108. Bryan, supra note 80 at para. 47.

109. Begum (Runa) v. Tower Hamlets LBC, [2003] 1 All E.R. 731 (H.L.) at para. 42 [Begum].

110. Immigration and Refugee Protection Act, S.C. 2001, c. 27, s. 96 [IRPA].

111.Ibid., s. 97.

112. The agency and portfolio were created by Order in Council on December 12, 2003: Order Transferring Certain Portions from the Department of Citizenship and Immigration to the Canada Border Services Agency, S.I./2003-215, C. Gaz. 2003.II.3231.

113.IRPA, supra note 110 , s. 6 .

114. Ibid., s. 100(1).

115. Ibid., s. 101.

116. Canada, Immigration and Refugee Board, The Refugee Protection Claim Process, online: <http://www.irb-cisr. gc.ca/en/about/tribunals/rpd/claimant/claimproc01_e. htm $>$ [Claim Process].

117. IRPA, supra note 110, s. 100(4).
118. Citizenship and Immigration Canada, Immigration Manual PP-1, "Processing Claims for Protection in Canada" (7 January 2005), online: <http://www.cic.gc.ca/manualsguides/english/pp/pp01e.pdf $>$ at 38-41 [PP-1].

119. Refugee Protection Division Rules, SOR/2002-228, ss. 1, 5, and 6 [RPD Rules].

120. IRPA, supra note 110, s. 112.

121. Ibid., s. 114(1).

122. Ibid., s. 112(2)(b).

123. Agreement Between the Government of Canada and the Government of the United States of America for Cooperation in the Examination of Refugee Status Claims from Nationals of Third Countries, 5 December 2002, online: $<$ http:// www.cic.gc.ca/english/policy/safe\%2Dthird.html> [Safe Third Country Agreement or Agreement]. The Agreement entered into force on December 29, 2004: CIC, Canada-US Safe Third Country Agreement, online: <http:/www.cic. gc.ca/English/ policy/menu-safethird.html > (last modified June 30, 2005).

124. Ibid., art. 4. Similarly, the Agreement allows the return to Canada of asylum seekers arriving in the United States from Canada. On 29 November 2007, the Federal Court of Canada declared that the regulations that operationalized the Agreement were ultra vires the IRPA because the United States did not comply with its international obligations towards refugees and was not a safe country. It also held that the regulations violated the Canadian Charter: Canadian Council for Refugees v. Canada, 2007 FC 1262 [CCR]. The Federal Court of Appeal overturned the trial judgment, finding that the designation of the United States as a safe country was lawful so long as the Governor-in-Council was of the opinion that the United States complied with its international obligations, regardless of its "actual compliance." It dismissed the Charter challenge, finding that the Canadian Council of Refugees, a Canadian NGO that advocates for refugees, did not have standing to challenge the regulations under the Charter and that there was an insufficient factual basis upon which to find a Charter breach: 2008 FCA 229 [CCR FCA].

125. Agreement, ibid., art. 4(2)(a)-(b); Immigration and Refugee Protection Regulations, SOR/2002-227, ss. 159.5(a)-(d) [IRP Regs].

126. Agreement, ibid., art. 4(2)(c); IRP Regs, ibid., s. 159.5(e).

127. Agreement, ibid., art. 6. A claimant will not be returned to the United States if she faces the death penalty there, is being charged or convicted in another country of an offense punishable by the death penalty in that country, or is a national or stateless former habitual resident of a country subject to a Canadian moratorium on removals: IRP Regulations, ibid., s. 159.6.

128. Agreement, supra note 123, Statement of Principles, Principle 3 [Statement of Principles].

129. PP-1, supra note 118 at para. 17.23. 
130. Ibid. at para. 17.13. Canadian officials may also reconsider negative eligibility determinations at the request of a US port director: ibid. at para.17.19.

131. IRPA, supra note 110, s. 153(2).

132. The SAB comprises three members jointly appointed by the Minister and IRB Chair and three members appointed by the IRB Chair: CIC, News Release, "Minister Finley announces revised selection process for appointments to the IRB" (9 July 2007). online: <www.cic.gc.ca/english/department/media/releases/2007/2007-07-09.asp> [CIC release].

133. IRPA, supra note 110, ss. 153(1)(a),(c). The Act provides that no less than 10 per cent of RPD members must be barristers or notaries.

134. Ibid., s. 162(1).

135. Ibid., s. 163. Under the former Immigration Act, R.S.C. 1985 , c. I-2, claims were heard by two-member panels unless the claimant consented to a single-member panel: ss. 69.1(7), (8).

136. RPD Rules, supra note 119 , s. 16.

137. Thamotharem v. Canada (Minister of Citizenship and Immigration), 2006 FC 16 (T.D.) at paras. 70-1, reversed on other grounds, 2007 FCA 198 at para. 44.

138. IRPA, supra note 110, s. 170(c).

139. See, for example, Canada, IRB, Guideline 7 - Concerning Preparation and Conduct of a Hearing in the Refugee Protection Division (1 December 2003), online: <http://www.irbcisr.gc.ca/en/about/guidelines/preparation_e.htm $>$ at para. 19.

140. IRPA, supra note 110, s. 107(1).

141. Ibid., ss. 169(b), (d).

142.Ibid., s. 25.

143.Ibid., s. 110(1).

144. IRPA, supra note 110, s. 112(1).

145.Ibid., s. 112(2)(b) and (d), respectively.

146. Claim Process, supra note 116 at para. 6.2; IRP Regs, s. 244(c), s. 160.

147. IRP Regs, ibid., s. 160. If she applies for a PRRA within the fifteen-day deadline, her removal is stayed until the application is decided: ibid., s. 162 .

148. IRPA, supra note 110, s. 113(a). See also Lorne Waldman, Canadian Immigration \& Refugee Law Practice (Toronto: LexisNexis Butterworths, 2004) at 375. Previously, the Immigration Act allowed such claimants to file a fresh claim for refugee protection and be heard again by the IRB, providing they had been outside of Canada for ninety days: Immigration Act, R.S.C. 1985, c. I-2, ss. 46.01(1)(c) and (5).

149. IRPA, supra note 110, s. 113(c). In certain circumstances, the PRRA officer may determine that an in-person hearing is required: IRP Regs, supra note 125, s. 167.

150. IRPA, ibid., s. 114(1)(a).

151. Ibid., s. 25. They may make an H\&C application at the time they submit their protection claim.

152. Citizenship and Immigration Canada, IP5 - Immigrant Applications in Canada made on Humanitarian or Com- passionate Grounds (12 January 2005), online: <http:// www.cic.gc.ca/manuals-guides/english/ip/ip05e.pdf>.

153. Ibid. at 8, para. 5.1.

154. Ibid. at para. 13.1.

155. Ibid. at 32, para. 13.6 .

156.IRPA, supra note 110., s. 72(2)(b).

157. IRPA, supra note 110, s. 72(d).

158. Bains v. Canada (M.E.I.) (1990), 47 Admin. L. R. 317 (FCA) at para. 1.

159. Ibid. at para. 4 .

160. Coliseum v. Canada (M.E.I.) (1991), 13 Imm. L.R. (2d) 24 (F.C.T.D.) at para. 4.

161. Krishnapillai v. Canada (Minister of Citizenship and Immigration), [2001] F.C.J. No. 1828 (C.A.) at paras. 28-31, online: QL (FCJ).

162.IRPA, supra note 110, s. 72(2)(e).

163. Federal Court of Canada, Activity Summary-January 1 to December 31, 2007, online: <http://cas-ncr-nter03.cas-satj. gc.ca/portal/page/portal/fc_cf_en/Statistics $>$.

164. Federal Court Act, R.S.C. 1985, c. F-7, s. 18.1(4). To obtain relief, the applicant must establish that the decision maker acted without jurisdiction, acted beyond its jurisdiction, or refused to exercise its jurisdiction; failed to observe a principle of natural justice, procedural fairness, or other procedure that it was required by law to observe; erred in law in making a decision or an order, whether or not the error appears on the face of the record; based its decision or order on an erroneous finding of fact that it made in a perverse or capricious manner or without regard for the material before it; acted, or failed to act, by reason of fraud or perjured evidence; or acted in any other way that was contrary to law.

165. Ibid., s. 18.1(3).

166. IRPA, supra note 110, s. 74(d).

167. Samoylenko v. Canada (M.C.I.) (1996), 116 F.T.R. 144 (T.D.) [Samoylenko].

168. Canada (M.C.I.) v. Liyanagamage, [1994] F.C.J. No. 1637 (C.A.).

169.Pushpanathan v. Canada (M.C.I.), [1998] 1 S.C.R. 982 at para. 25.

170. Ibid. at paras. 29-38.

171. Dunmsuir v. New Brunswick, 2008 SCC 9 [Dunsmuir].

172. Law Society of New Brunswick v. Ryan 2003 SCC 20 at para. 44.

173. Canada (Director of Investigation and Research) v. Southam Inc., [1997] 1 S.C.R. 748 [Southam] at 776-7.

174. Dunsmuir, supra note 171 at paras. $45-48$.

175. Ibid. at para. 53.

176. Ibid. at paras 43-49. See also Mugesera v. Canada, 2005 SCC 40 at para. 37 [Mugesera], which discusses the standard of review for decisions of the IRB's Immigration Appeal Division.

177. Mugesera, ibid. at para. 38. See Dhindsa v. Canada (M.C.I.), [2000] F.C.J. No. 2011 (QL) at para. 41-44 where the Federal Court held that it would "not revisit the facts and weigh 
the evidence" or set aside credibility findings unless they were "clearly made without regard to the evidence", i.e., if the evidence, viewed reasonably, was "incapable of supporting the tribunal's findings of fact."

178. Sivasamboo v. Canada (M.C.I.) [1994] F.C.J. No. 2018 at para. 22, online: QL (FCC).

179. See for example, Khokhar v. Canada (Minister of Citizenship and Immigration), $2008 \mathrm{FC} 449$ at para. 23.

180. Sounitsky v. Canada (Minister of Citizenship and Immigration), 2008 FC 345 at para. 18. Before Dunsmuir, most judges, noting that PRRA officers base their risk assessments on new evidence pointing to "changed circumstances," concluded that PRRA decisions involved questions of fact and upheld them unless they were patently unreasonable or involved erroneous findings made in a perverse or capricious manner: Joseph v. Canada (M.C.I.), [2004] F.C.J. No. 392 at para. 10 (T.D.), online: QL (F.C.C.).

181. Baker, supra note 29.

182. A "non-independent" decision maker lacks the objective guarantees of independence required of tribunals by conventional international law, including security of tenure, financial security and actual independence-in appearance and practice-from the executive and legislature, and is not necessarily actually or subjectively biased.

183. This argument is also elaborated in Heckman \& Sossin, supra note 105 at 248 et seq. Claimants who fail to obtain leave receive an even less intense review.

184. The section "Critiques of the Canadian System by Treaty Bodies," below, discusses reports by the Inter-American Commission on Human Rights and views of the United Nations Committee Against Torture.

185. The Minister of Citizenship and Immigration may discipline or remove them from office before completion of their term only in exceptional circumstances, at the IRB Chair's request and following a public inquiry conducted by a Superior Court judge: IRPA, supra note 110, s. 176 . Members must either be incapacitated, be found guilty of misconduct, fail in the proper execution of their office, or be placed in a position incompatible with the due execution of their office.

186.Ibid., s. 153(d).

187.Ibid., s. 159.

188. Under a system established by the federal government in 2004 to put an end to a history of rampant patronage in the selection of IRB members, an advisory panel of six members chosen and chaired by the IRB Chair carried out a merit-based, non-partisan assessment of candidates for IRB positions and provided the names of qualified candidates to the IRB Chair. These candidates' competences were further assessed by the Chair and expert IRB staff. The Minister of Citizenship and Immigration could then appoint members from a list of qualified candidates. Since July 2007, the Minister participates in selecting three of the six members of the advisory panel: CIC Release, supra note 132. Following this change, the IRB's Chair resigned his position, as did the members of the independent advisory panel, some of whom raised concerns that the government was seeking to re-politicize the refugee determination process; see Bruce Campion-Smith, "PM defends refugee board changes" Toronto Star (1 March 2007).

189. But see François Crépeau \& Delphine Nakache, "Critical Spaces in the Canadian Refugee Determination System: 1989-2002" (2008), 20 I.J.R.L. 50.

190. [1989] 2 F.C. 363 (C.A.), aff'g [1988] 3 F.C. 308 (T.D.), leave to appeal to SCC refused (1989) 101 N.R. 157 (note) (S.C.C.) [Mohammad].

191. IAT members were appointed by the Governor-in-Council for fixed terms not exceeding ten years and held office during good behaviour.

192. Mohammad (T.D.), supra note 190 at para. 55 .

193. Mohammad, supra note 190 at para. 76 .

194. The Court minimized the connections between the Adjudication Directorate and the Enforcement Branch and overemphasized the significance of a generic oath of office and job description. Purporting to focus on objective guarantees that support a perception of sufficient institutional distance between adjudicators and the executive, it relied on a retired adjudicator's "feeling" that final decisions on a case were solely his, but downplayed his testimony that a superior officer had questioned the merits of his decisions.

195. An act to amend the Immigration Act and other acts in consequence thereof, S.C. 1992, c. 49, s. 47(1).

196. Immigration Act, R.S.C. 1985, c. I-2, s. 58(3).

197. Ahumada v. Canada (M.C.I.), [2001] F.C. 605 (C.A.) at para. 57.

198. Ibid. at para. 46.

199. Ibid. at paras. 54-55.

200. OAS, Inter-American Commission on Human Rights, Report on the Situation of Human Rights of Asylum Seekers within the Canadian Refugee Determination System, OEA/ Ser.L/V/II.106/Doc. 40 rev. February 28, 2000 at para. 64 [IACHR Report].

201. Nalliah v. Canada (Solicitor General), [2004] F.C.J. No. 2005 (T.D.), online: QL (FCC) [Nalliah].

202. Order Transferring Certain Portions from the Department of Citizenship and Immigration to the Canada Border Services Agency, S.I./2003-215, C. Gaz. 2003.II.3231 [emphasis added]. PSEP's portfolio includes emergency preparedness, national security, corrections, policing, oversight, crime prevention, and border services: Canada Border Services Agency, About the CBSA, online: <http://www.cbsa.gc.ca/ agency/menu_e.html> (date accessed: 25 February 2005).

203. Canadian Council for Refugees, News Release, "New Border Agency Threatens Refugee Protection in Canada" (8 January 2004), online: <http://www.web.ca/ ccr > (date accessed: 25 February 2005).

204. Order Transferring to the Department of Citizenship and Immigration the Control and Supervision of Certain Portions within the Canada Border Services Agency and Transferring from the Deputy Minister and Minister of Public Safety 
and Emergency Preparedness to the Minister of Citizenship and Immigration Certain Powers, Duties and Functions, S.I./2004-135, C. Gaz. 2004.II.1614; Government of Canada, News Release, "Government of Canada announces transfer of certain functions between Citizenship and Immigration Canada and the Canada Border Services Agency" (12 October 2004).

205. Challenges to PRRA applications conducted by CIC before the transfer of PRRA to CBSA have failed. See, for example, Ariri v. Canada (M.C.I.) (12 February 2003), IMM-871-03 (F.C.T.D.).

206. 2005 FC 739 (T.D.), upheld 2005 FCA 422, leave to appeal denied, [2006] S.C.C.A. No. 49, online: QL [Say].

207. Applicant's Memorandum of Fact and Law-Application for leave and judicial review, Nalliah v. Canada (M.C.I.; Solicitor General), IMM-9071-04 at para. 37.

208. Much of the information upon which this discussion is based is drawn from the Affidavits of Himmat Shinhat, Audrey Mitchell, and Michelle Tiffney, Respondent's Motion Record, Nalliah v. Canada (M.C.I.; Solicitor General), IMM-9071-04.

209. Citizenship and Immigration Canada, Immigration Manual PP-3, "PPRA" (June 2002), online: <http://www.cic.gc.ca/ manuals-guides/english/pp/pp03e.pdf $>$ at paras. 5.14 and 7 [PP3].

210. PP3, supra note 209 at 26 , para. 7.

211. The Policy Unit provides interpretations of legislation, policy, and case law, advises on specific factual scenarios, and answers questions from individual PRRA officers regarding the appropriate application of the IRPA, IRPA Regulations and PRRA policy.

212. A training presentation on protecting PRRA officers from undue influence in the exercise of their duties states that PRRA and removals functions may be co-located "if a separate reporting structure is in place": Shinhat affidavit, supra note 208, Exhibit "C".

213. Tiffney affidavit, supra note 208 at para. 23.

214. Nalliah alleged that PRRA decisions had been expedited to meet removal dates scheduled by the enforcement unit, a claim denied by the government: Affidavit of Brena Parnes, Applicant's Motion Record, Nalliah v. Canada (M.C.I.; Solicitor General), IMM-9071-04 at para. 27.

215. Respondent's Memorandum of Argument, Nalliah v. Canada (M.C.I.; Solicitor General), IMM-9071-04 at para. 31 [Nalliah Memorandum].

216. Shinhat affidavit, supra note 208 at para. 25; Immigration and Refugee Protection Regulations, Regulatory Impact Analysis Statement (15 December 2001) Canada Gazette Part I 4477 at 4554 [RIAS]. See also Sing v. Canada (Minister of Citizenship and Immigration), 2007 FC 361, where the Federal Court, citing Say, determined that there was no reasonable apprehension that a PRRA officer's risk assessment decision would be biased against a protection claimant because the Minister had intervened against the claimant in prior IRB proceedings. The official who had intervened against the claimant and the PRRA officer were in two different units within CIC and each decision-maker had acted within its own statutory mandate. The Court noted, at para. 75, that "PRRA officers are professional decisionmakers, undoubtedly very much aware that their decisions are subject to the constraints imposed upon each and every decision made on a quasi-judicial basis."

217. Say, supra note 215 at para. 39 .

218. Nalliah Memorandum, supra note 215 at para. 40.

219. See Ettl, supra note 85.

220. See Morris, supra, note 89. Contrary to the junior members of the Court Martial in Cooper, supra note 91, PRRA officers' views are subject to the scrutiny of superiors.

221. Say, supra note 206 at para. 44 .

222. It is noteworthy that the Federal Court of Appeal has held that PRRA officers do not have jurisdiction to determine whether their enabling statute is constitutional or not: $\mathrm{Co}$ varubias v. Canada (Minister of Citizenship and Immigration), 2006 FCA 365, [2006] F.C.J. No. 1682 (QL); Singh v. Canada (Minister of Citizenship and Immigration), 2004 FC 288, [2004] F.C.J. No. 346. Writing extrajudicially, Federal Court Justice John Evans has suggested that such decisions recognize that immigration officers "lacked both the independence and the procedural powers needed to build a record that could form the basis on which a court could review a determination of a constitutional question": John Evans, "Principle and Pragmatism: Administrative Agencies' Jurisdiction over Constitutional Issues" in Grant $\mathrm{Hu}$ scroft \& Michael Taggart, eds., Inside and Outside Canadian Administrative Law (Toronto: University of Toronto Press, 2006) 377 at 403.

223. IRPA, supra note 110, s. 112(2)(b).

224. CCR, supra note 124 at paras. 154 and 191. The Court held that the stringent application by US authorities of a bar on asylum claims filed after one year, combined with the higher burden on protection claimants to successfully apply for withholding of removal, put claimants returned to the US at risk of refoulement, contrary to the Refugee Convention. It found that the US statutory provisions requiring the exclusion of persons who involuntarily provided support to terrorist groups also subjected claimants returned to the US to a serious risk of refoulement. The Federal Court of Appeal overturned this decision because, in its view, the motions judge improperly entertained the Charter challenge in the absence of a proper factual foundation: CCR FCA, supra note 124 at para. 103. It did not hold that such a challenge could not succeed in an appropriate case, advanced by a refugee claimant found ineligible under the Safe Third Country Agreement and who faced a real risk of refoulement in being sent back to the United States.

225. To uphold claimants' right to an independent adjudication of their claim, immigration officers have no choice but to invoke the public interest exception to the application of the Safe Third Country Agreement and find that claimants caught by the US one-year bar and "material support" 
provisions are eligible to have their claims determined by the RPD. Automatic referral of such claims to the RPD for adjudication would be compatible with the expeditious administrative process contemplated by the statutory scheme. But see CCR FCA, supra note 124 at paras. 124-125, where, in a concurring judgment, Evans J.A. contemplates that CBSA officers themselves (assisted by guidelines) would make eligibility decisions for claimants who assert they will be refouled if returned to the United States under the Safe Third Country Agreement.

226. 2 May 1948, 43 A.J.I.L. 133.

227. IACHR Report, supra note 200 at para. 60. The Commission linked this right to be heard to "the principle of respect for due process which underlies various provisions of the American Declaration, most pertinently arts. II (equal protection), XVII (recognition of judicial personality and civil rights), XVIII (fair trial), and XXVI (due process)."

228. Ibid. at para. 64.

229. Ibid. at para. 70 [emphasis added].

230. Can. T.S. 1987 No. 36 [CAT].

231. Committee Against Torture, 25th Session, Concluding observations of the Committee against Torture : Canada. 22/11/2000, A/56/44, at para. 58(f).

232. Ibid. at para. 59(b) [emphasis added].

233. Committee Against Torture, 34th Session, Conclusions and Recommendations of the Committee Against Torture: Canada. 07/07/2005, CAT/C/CR/34/CAN. At para. 5(c).

234. Committee Against Torture, Communication No. 133/1999, Enrique Falcon Ríos v. Canada, UN Doc. CAT/ C/33/D/133/1999 (17 December 2004).

235. The IRB panel's adverse credibility findings against Ríos have been criticized for their reliance on stereotypes and a lack of basic knowledge regarding the political situation in Chiapas: Cécile Rousseau et al., "The Complexity of Determining Refugeehood: A Multidisciplinary Analysis of the Decision-making Process of the Canadian Immigration and Refugee Board" (2002) 15 J. of Refugee Studies 43 at 59,61 , and 62 .
236. Ibid. at para. 7.3.

237. A court reviewing the $\mathrm{H} \& \mathrm{C}$ decision would not substitute its own views for that of the $\mathrm{H} \& \mathrm{C}$ officer but would remit the case to another non-independent officer.

238. Ibid. at para. 7.5.

239. Ibid. at paras. 8.6, 9 .

240. Committee Against Torture, Communication No. 273/2005, T.A. v. Canada, UN Doc. CAT/C/36/D/273/2005 (22 May 2006) [T.A.].

241. T.A., ibid. at para. 6.4; Committee Against Torture, Communication No. 183/2001, B.S.S. v. Canada, UN Doc. CAT/C/32/D/183/2001 (17 May 2004) at para. 11.6; Communication No. 282/2005, S.P.A. v. Canada, UN Doc. CAT/ $\mathrm{C} / 37 / \mathrm{D} / 282 / 2005$ (6 December 2006) at para. 7.4.

242. IRPA, supra note 110, s. 3(3)(f).

243. Gerald P. Heckman, Prospects for Narrowing the Gap between Domestic and International Institutional and Procedural Safeguards in Canadian, American and Australian Refugee Protection Decisionmaking (Ph.D. Thesis, Osgoode Hall Law School, York University, 2008) [unpublished].

244. Hape, supra note 9. Canada's international human rights obligations only inform the content of Charter protections: Suresh v. Canada (Minister of Citizenship and Immigration), [2002] 1 S.C.R. 3. at para. 60.

Gerald P. Heckman (Ph.D., Osgoode Hall Law School) is Assistant Professor, Faculty of Law, University of Manitoba, Winnipeg, MB, Canada. The author acknowledges the valuable research assistance of Julia Negrea, LL.B. student, Faculty of Law, University of Manitoba and the financial support of the Legal Research Institute of the University of Manitoba. The author also thanks the anonymous reviewer and the editorial staff at Refuge for their thoughtful comments and suggestions. To the extent feasible, the law as stated in this article is current to June 2008.

(C) Gerald P. Heckman, 2008. This open-access work is licensed under a Creative Commons Attribution-NonCommercial 4.0 International License, which permits use, reproduction and distribution in any medium for non-commercial purposes, provided the original author(s) are credited and the original publication in Refuge: Canada's Journal on Refugees is cited. 